\title{
ASIAN-AFRICAN LEGAL CONSULTATIVE COMMITTEE BI-ANNUAL SURVEY OF ACTIVITIES 1997-1999
}

including the work of its Thirty-seventh Session, held in New Delhi, 13-18 April 1998 and Thirty-eighth Session, held in Accra, 19-23 April 1999

\section{M.C.W. Pinto*}

Note: The Sessions of the Asian-African Legal Consultative Committee, which was established on 15 November 1956 to facilitate the exchange of views and information on legal matters of common concern to its Members, are convened alternately in Asia and Africa. A Session generally takes place in the first half of a calendar year, and is known by the name of the city in which it is held. Consideration of a topic commenced at one Session, may continue in the inter-sessional period through seminars or expert group meetings; these retain their association with the originating Session. Reports on inter-sessional activities may be discussed at the following Session.

The present survey refers to work taken up at the Thirty-seventh (New Delhi, 1998) and Thirty-eighth (Accra, 1999) Sessions, while containing references also to activities associated with the Thirty-fifth (Manila, 1996) and Thirty-sixth (Tehran, 1997) Sessions, which were covered in volumes 6 and 7 of this Yearbook. Prepared for a combined volume 8/9 of this Yearbook, constraints on space have required greater conciseness than usual in referring to the wealth of material generated under the auspices of the Committee.

\section{MEMBERSHIP AND ORGANIZATION}

1. There were forty-three Members of the Committee at the time of its Thirtyseventh and Thirty-eighth Sessions, held respectively at New Delhi, India, from 13-18 April 1998, and at Accra, Ghana, from 19-23 April 1999: Bahrain, Bangladesh, China,

\footnotetext{
* General editor.
} 
Cyprus, Egypt, Gambia, Ghana, India, Indonesia, Iran, Iraq, Japan, Jordan, Kenya, Democratic People's Republic of Korea, Republic of Korea, Kuwait, Libya, Malaysia, Mauritius, Mongolia, Myanmar, Nepal, Nigeria, Oman, Pakistan, Palestine, Philippines, Qatar, Saudi Arabia, Senegal, Sierra Leone, Singapore, Somalia, Sri Lanka, Sudan, Syria, Tanzania, Thailand, Turkey, Uganda, United Arab Emirates, and Yemen. Botswana is an Associate Member.

\section{Officers of the Thirty-seventh (New Delhi) Session}

2. The Thirty-seventh Session of the Committee elected Dr. P. SREENIVASA RAO, Joint Secretary and Legal Adviser to the Ministry of External Affairs of the Government of India, as its President. Dr. MARTIN A.B.K. AMIDU, Deputy Minister of Justice and Deputy Attorney-General of the Government of Ghana, was elected Vice-President of the Session.

3. The President of the Session, Dr. P.S. RAO and the Vice-President, Dr. MARTIN AMIDU, served as Chairman and Vice-Chairman respectively of the Special Meeting on Reservations to Treaties, held on 14 April 1998 in connection with the Committee's Thirty-seventh Session.

\section{Officers of the Thirty-eighth (Accra) Session}

4. The Thirty-eighth Session of the Committee elected Dr. MARTIN A.B.K. AMIDU, Deputy Minister of Justice and Deputy Attorney-General of the Government of Ghana, as its President. Mr. ABdulla Ahmed Ghanim, Minister for Legal Affairs of the Government of the Republic of Yemen, was elected Vice-President of the Session.

\section{Meetings associated with Committee Sessions}

5. A Commemorative Seminar in connection with the thirtieth anniversary of the adoption of the Bangkok Principles concerning Treatment of Refugees (1966) was held from 11-13 December 1996 in Manila, Philippines, in connection with the Thirtyfifth (Manila) Session of the Committee. The Seminar was inaugurated by the President of the Manila Session, H.E. Mr. TEOFISTO GuINGONA, Secretary of Justice of the Government of the Philippines.

6. In connection with the Committee's Thirty-sixth (Tehran) Session, a Seminar held in Tehran from 24-25 January 1998, discussed the subject "Extra-territorial application of national legislation: sanctions imposed against third parties". The Seminar was inaugurated by Dr. M. JAVAD ZARIF, Deputy Minister for Foreign Affairs in Iran, and President of the Thirty-sixth Session.

7. Also in connection with the Committee's Thirty-sixth (Tehran) Session, a "Report of the Seminar to Commemorate the $30^{\text {th }}$ Anniversary of the Bangkok Principles held in Manila, Philippines" prepared by the AALCC Secretariat, was discussed at a Meeting of Experts in Tehran 11-12 March 1998, inaugurated by Dr. M. JAVAD 
ZARIF, Deputy Minister for Foreign Affairs of Iran, and President of the Thirty-sixth Session.

8. The discussion of the foregoing Reports and the action taken thereon form part of the record of the proceedings of the Committee's Thirty-seventh (New Delhi) Session.

9. In connection with the Committee's Thirty-seventh (New Delhi) Session, meetings convened under the auspices of the Committee, and presided over by the President of the Session, Dr. P. SREENIVASA RAO, discussed (1) the Establishment of an International Criminal Court, Rome, Italy (June/July 1998; (2) Certain Aspects of the Functioning of the WTO Dispute Settlement Mechanism, New Delhi, 17-18 November 1998; (3) Human Rights in the United Nations, New Delhi, 14 January 1999; and (4) Themes of the First International Peace Conference (1899), New Delhi, 11-12 February 1999.

10. In connection with the Committee's Thirty-eighth (Accra) Session, a meeting convened under the auspices of the Committee discussed the subject Effective means of implementation, enforcement and dispute settlement in international environmental law on 20 April 1999. The meeting was presided over by Dr. MARTIN A.B.K. AMIDU, Deputy Minister of Justice and Deputy Attorney-General of Ghana, President of the Thirty-eighth (Accra) Session. Mr. SIRILIUS MATUPA, Senior State Attorney of the Government of Tanzania, acted as Rapporteur.

\section{Organization of the Sessions and Associated Meetings}

11. The organization of Sessions and associated meetings was the responsibility of the Secretary-General of the Committee, Mr. TANG CHENGYUAN, who was assisted by Mr. WAFIK ZAHER KAMIL, Mr. MOHAMMED REZA DABIRI and Mr. RYO TAKAGI, Deputy Secretaries-General, as well as by the Assistant Secretaries-General, and members of the Secretariat.

12. The Committee considered, and adopted decisions on the subjects listed below, the order of their discussion being determined at the commencement of each Session. The references next to each subject are to the pages of the Reports of each Session: ND-New Delhi, A-Accra.

\section{Questions under consideration by the International Law Commission} (1998 (New Delhi) Report, pp. 129-288)

(1999 (Accra) Report, pp. 138-221) 


\section{Matters referred to the Committee by participating States}

- International rivers (1998 ND 197-219)

- Legal protection of migrant workers (1998 ND 425-438; 1999 A 353-370)

- Extra-territorial application of national legislation: sanctions imposed against third parties (1998 ND 345-399; 1999 A 11-137)

- Status and treatment of refugees (1998 ND 289-314; 1999 A 259-300)

- Deportation of Palestinians and other Israeli practices in violation of international law (1998 ND 315-344; 1999 A 301-21)

- Law of the Sea (1998 ND 15-51; 1999 A 16-25)

3. Matters of common concern having legal implications

- United Nations Conference on Environment and Development (1998 ND 40124; 1999 A 322-52)

- United Nations Decade of International Law (1998 ND 53-91; 1999 A 57-110)

- Establishment of an International Criminal Court (1998 ND 93-127; 1999 A 222-58)

4. Trade law matters

- Report on legislative activities of the United Nations and other international organizations in the field of international trade law (1998 ND 439-496; 1999 A 415-56)

- World Trade Organization; dispute settlement and related matters (1998 ND 497-535; 1999 A 374-414)

- Report on AALCC's Regional Arbitration Centres (1998 ND 9-13; 1999 A 11-13)

\section{LEGAL MATERIALS}

The Reports of the Thirty-seventh (New Delhi, 1998) and thirty-eighth (Accra, 1999) Sessions contain valuable legal materials in the form of summaries of discussions, or conclusions reached either by the Committee itself or by expert groups meeting under its auspices; as well as studies carried out by the Secretariat, which served as background material for the Committee's work.

Thus, the Report on the New Delhi (1998) Session contains a useful account of the progress of the work on the Law of the Sea at the United Nations from the signing of the 1982 UN Convention on the Law of the Sea, through the conclusion of the 1994 Agreement Relating to the Implementation of Part XI of the Convention, and the 1995 Agreement for the Implementation of the Convention Relating to the Conservation and Management of Straddling Fish Stocks and Highly Migration Fish Stocks, including lists of States Parties, and the results of the first elections to the various organs constituted pursuant to the 1982 Convention (pages 15-51); a Secretariat study on the Establishment of the International Criminal Court (pages 107-27); a summary of the Committee's concluding deliberation on the Law of International Rivers (pages 197-219); a summary of the work of the International Law Commission on Reservations to Treaties (pages 221-66); a Secretariat study on a draft of proposals for revision of the Bangkok Principles concerning the Treatment of Refugees, see 
AsianYIL, Vol. 7 at pages 381-7 (pages 297-314) (reproduced below, 201-211); a background note on the Extra-territorial application of national legislation prepared by the Secretariat for the Seminar on the subject held at Tehran on 24-25 January 1998, and an account of the deliberations of the seminar by Professor V.S.MANI (pages 345-93) (excerpts from which are reproduced below, 211-226); a Report on the Special Session of the UN General Assembly for the purpose of an Overall Review and Appraisal of the Implementation of Agenda 21 (pages 406-24); and a study by the Secretariat on the working of the World Trade Organization's Dispute Settlement Mechanism (pages 497-536) (partly reproduced below, 227-233).

Materials contained in the Report on the Thirty-eighth (Accra, 1999) Session include a summary of the Committee's work on Extra-territorial application of national legislation and a Secretariat study noting recent developments in the field (pages 111-37) (excerpts reproduced below, 233-242); a Report of a Special Meeting on Reservations to Treaties (pages 212-21) (excerpts reproduced below, 242-245); a Report by the Secretariat on the Committee's participation at the Rome Conference of Plenipotentiaries on the Establishment of an International Criminal Court 15 June - 17 July 1998, and a Secretariat Overview of the Rome Statute (pages 222-58); the Report of a Special Meeting on effective means of implementation, enforcement and dispute settlement in international environmental law, including a Secretariat study on the subject (pages 322-52) (conclusions reproduced below, 245-246); and the Report of a seminar on Certain Aspects of the Functioning of the WTO Dispute Settlement Mechanism and other Allied Matters (New Delhi, 17-18 November 1998 (pages 365-414).

In accordance with its practice, the Committee regularly includes in its Reports materials aimed at keeping Members currently informed of developments regarding the deportation and treatment of Palestinians in violation of international law; of measures for the protection of migrant workers; of the legislative activities of the United Nations and other organizations concerned with international trade law, and of the work of the Committee's regional arbitration centres at Kuala Lumpur, Cairo, Lagos, and Tehran. 


\section{ANNEXES*}

\section{A. Secretariat Study: STATUS AND TREATMENT OF REFUGEES ${ }^{1}$ \\ (Expert Group Meeting, Tehran, 11-12 March 1998)}

$\cdots$

The 'draft' will be sent to the participants in the Expert Group Meeting with a view to invit[ing] their comments. Once these comments are received, the Secretariat will prepare the final record as well as an in-depth study as recommended by the Expert Group Meeting. A paper containing revised proposals for the Bangkok Declaration has also been included in this study. This has been prepared taking into account the recommendations of the Manila Seminar and the views expressed at the Expert Group Meeting in Tehran.

\section{REVISED PROPOSALS FOR 'BANGKOK PRINCIPLES'}

\section{The Refugee Definition}

\section{Article 1: Definition of the term "Refugee"}

1. A refugee is a person who, owing to persecution or a well-founded fear of persecution for reasons of race, colour, [religion,] nationality, ethnic origin, ${ }^{3}$ political opinion $^{4}$ (or) membership of a particular social group:

(a) leaves the State of which he $e^{5}$ is a national, or the Country of his nationality, or, if he has

\footnotetext{
* [Yearbook editorial note: Footnotes in the following texts are numbered consecutively as they appear in this reproduction of the main text of the Annexes and not separately for each Annex. For this reason and because only parts of the original main text are reproduced here, the numbering differs from that in the original Annexes.]

${ }^{1}$ [Yearbook editorial note: The following text is the reproduction of the relevant AALCC document. Despite the risks involved the Editors have decided to alter and correct suspected typing errors. These errors do not consist solely of spelling errors but also of deletions from the original Bangkok Declaration in the absence of any indication of intended change.]

${ }^{2}$ In this draft, the parts in regular characters are from the Bangkok Principles, their Exceptions, Explanations, Notes, and Addenda. The texts in italics come from other sources, including recommendations of the Manila Seminar or the Tehran Meeting of Experts, and provisions of other international instruments. All sources other than Articles of the Bangkok Principles are specified in footnotes.

3 Both the Manila Seminar and [the] Tehran Meeting of Experts strongly recommended adding the ground of "nationality". The Tehran Meeting of Experts recommended "ethnic origin".

4 The term "opinion" is used in all the other international refugee definitions, instead of "belief".

5 It may be preferable in these times to use, whenever appropriate, the formulas: "he/she" and "his/ her".
} 
no nationality, the State or Country of which he is a habitual resident; and ${ }^{6}$

(b) being outside of such a State or Country, is unable or unwilling to return to it or to avail himself of its protection.

2. The term "refugee" shall also apply to every person who, owing to external aggression, occupation [and?or?] foreign domination or event seriously disturbing public order in either part or the whole of his country of origin or nationality. ${ }^{7}$

3. A person who was outside of the State of which he is a national or the Country of his nationality or, if he has no nationality, the State of which he is a habitual resident, at the time of the events which caused him to have a well-founded fear of the above-mentioned persecution, and is unable or unwilling to return or to avail himself of its protection shall be considered a refugee. ${ }^{8}$

4. The dependents of a refugee shall be deemed to be refugees. ${ }^{9}$

5. A person having more than one nationality shall not be a refugee if he is in a position to avail himself of the protection of any State or Country of which he is a national. ${ }^{10}$

6. A refugee shall lose his status as refugee if: ${ }^{11}$

(i) he voluntarily returns to the State of which he was a national, or the Country of which he was a habitual resident; or

(ii) he has voluntarily re-availed himself of the protection of the State or Country of his nationality; it being understood that ${ }^{12}$ at the loss of status as a refugee under

6 Recommended as a substitute for 'or' in Note (iv) to Art. 1 of the Bangkok Principles: this is also consistent with all other international refugee definitions.

${ }^{7}$ Art.1(2) of the OAU Convention governing the Specific Aspects of Refugee Problems in Africa. This addition was recommended both at the Manila Seminar and at the Tehran Meeting of Experts. This paragraph also reflects Note (ii) to Art.1 of the Bangkok Principles which refers to "invasion" and "occupying" of the State of origin, and para. 1 of the 1970 Addendum to the Bangkok Principles, which lists "foreign domination, external aggression or occupation". In conformity with the discussions at the Tehran Meeting of Experts, it does not include the formula of the 1983 Cartagena Declaration on Refugees which refers to "generalized violence, [...] internal conflicts, massive violation of human rights [...]". One participant at the Tehran Meeting of Experts was unfavourable to expansion of the definition.

8 Note (vi) to Art.1 of the Bangkok Principles.

9 Explanation of Art.1 of the Bangkok Principles.

10 Exception (1) to Art.1 of the Bangkok Principles.

1 This paragraph is Art.2 (loss of refugee status) of the Bangkok Principles: the latter's cessation provisions, with some modifications derived from the Notes to the same Article and from the 1951 Convention.

${ }_{12}$ Stylistic addition. 
this $s u b^{13}$-paragraph will take place only when the refugee has successfully reavailed himself of the protection of the State of his nationality; ${ }^{14}$ or

(iii) he voluntarily acquires the nationality of another State or Country and is entitled to the protection of that State or Country; or

(iv) (...) he does not return to the State of which he is a national, or to the Country of his nationality, or if he has no nationality, to the State or Country of which he was a habitual resident, or if he fails to avail himself of the protection of such State or Country after the circumstances in which he became a refugee have ceased to exist.

Provided that this paragraph shall not apply to a refugee ... who is able to invoke compelling reasons arising out of previous persecution for refusing to avail himself of the protection of the Country of nationality. ${ }^{15}$

7. A person ${ }^{16}$ who, prior to his admission into the Country of refuge, has committed a crime against peace, a crime against humanity as defined in international instruments drawn up to make provisions in respect of such crimes $^{17}$ or a serious nonpolitical crime outside his Country of refuge prior to his admission to that country as a refugee, ${ }^{18}$ or has committed acts contrary to the purposes and principles of the United Nations, shall not be a refugee.

\section{Asylum and Treatment of Refugees}

\section{Article III: Asylum to a Refugee}

1. Everyone, without any distinction of any kind, is entitled to the right to seek and to enjoy in other countries asylum from persecution. ${ }^{19}$

13 Idem.

14 This sentence is derived from Note (ii) to Art.2 of the Bangkok Principles.

15 Art.1(C)(5) of the 1951 Convention. This sub-paragraph usefully complements the rest of the text, the core of which is protection, as repeatedly indicated at the Tehran Meeting of Experts. It is also consistent with the recommendations of a participant at the Tehran Meeting that the chances of justifying cessation of refugee status should be of a fundamental nature.

16 This paragraph is derived from Exception (2) of the Bangkok Principles. It is a set of Exclusion Clauses recommended at the Tehran Meeting of Experts. The text is modified to correspond to the formulations of existing universal and regional instruments on refugees, as specified below. One participant proposed a specific reference to terrorism as a ground for exclusion. It was pointed out that, if properly applied, the exclusion clauses as stated in this paragraph and indeed in all the major international refugee instruments, should exclude a terrorist. While the problem of terrorism is not to be denied, it was deemed important to avoid giving the erroneous impression that all refugees are terrorists, which would in turn undermine the institution of asylum.

17 Art.1(5)(a) of the OAU Convention and Art.1(F)(a) of the 1951 Convention.

18 Art.1(5)(b) of the OAU Convention and Art.1(F)(b) of the 1951 Convention.

19 Para. 23 of the 1993 Vienna Declaration on Human Rights. An alternative formulation might be: "Everyone has the right to seek and to enjoy in other countries asylum from persecution [...]". (Art.14(1) Universal Declaration of Human Rights. 
2. A State has the sovereign right to grant or to refuse asylum in its territory to a refugee in accordance with its international obligations and national legislation. ${ }^{20}$ 3. The granting of asylum to refugees is a peaceful and humanitarian act. ${ }^{21} I t^{22}$ shall be respected by all other States and shall not be regarded as an unfriendly act. 4. Member States shall use their best endeavours consistent with their respective legislations to receive refugees and to secure the settlement of those refugees who, for well-founded reasons, are unable or unwilling to return to their Country of origin or nationality. ${ }^{23}$

\section{Article IIIA: $:^{24}$ Non-refoulement}

1. No one seeking asylum in accordance with these principles shall be subjected to measures such as rejection at the frontier, return or expulsion which would in his life or freedom being threatened on account of his race, religion, nationality, ethnic origin, ${ }^{25}$ membership of a particular social group or political opinion. ${ }^{26}$

2. The provision as outlined above may not however be claimed by a person when there is reasonable ground to believe the person's presence is a danger to the security of the Country in which he is, or whom having been convicted by a final judgment of a particularly serious crime, constitutes a danger to the community of that Country. ${ }^{27}$

3. In cases where a State decides to apply any of the above-mentioned measures to a person seeking asylum, it should grant provisional asylum under such conditions it may deem appropriate, to enable the person thus endangered to seek asylum in another Country. ${ }^{28}$

\section{Article VI: Minimum standard of treatment}

\footnotetext{
20 This insert was recommended by the Manila Seminar and amended by the Tehran Meeting of Experts from "domestic" to "national". One participant also proposed placing the word "its" in front of "national".

${ }^{21}$ Art.II(2) of the OAU Convention and the preamble of the United Nations Declaration on Territorial Asylum.

22 Stylistic substitution.

23 Art.II(1) of the OAU Convention. This proposed paragraph would indeed reflect the positive State practice in the Afro-Asian region in the past three decades.

${ }^{24}$ The Manila Seminar proposed removing para.3 from Art.III of the Bangkok Principles and making it into a separate Article in two paragraphs, as per the first two paragraphs below. The third paragraph below is actually para.[4] of Art.III of the Bangkok Principles.

${ }^{25}$ The addition of "ethnic origin" in the non-refoulement provision was recommended at the Tehran Meeting of Experts. It is in any case consistent with the grounds in the refugee definition.

${ }^{26}$ Rephrasing of Art.III as per footnote 23 above.

27 Idem.

${ }^{28}$ Para.3 of Art.III as per footnote 23 above.
} 
1. A State shall accord to refugees treatment no less favourable than that generally accorded to aliens in similar circumstances, with due regard to basic human rights as recognized in generally accepted international instruments. ${ }^{29}$

2. The standard of treatment referred to in paragraph $I^{30}$ shall include the rights relating to aliens contained in the Final Report of the Committee on the status of aliens, to the extent they are applicable to refugees.

3. A refugee shall not be denied any rights on the ground that he does not fulfil requirements which by their nature a refugee is incapable of fulfilling.

4. A refugee shall not be denied any rights on the ground that there is no reciprocity in regard to the grant of such rights between the receiving State or the Country of nationality of the refugee or, if he is stateless, the State or Country of his former habitual residence.

5. States undertake to apply these principles to all refugees without distinction as to race, religion, nationality, ethnic origin, gender, membership of a particular social group or political opinions, in accordance with the principle of non-discrimination. ${ }^{31}$

6. States shall adopt effective measures for improving the protection of refugee women and, as appropriate, ensure that the needs and resources of refugee women are fully understood and integrated to the extent possible into their activities and programmes. ${ }^{32}$

7. States shall take appropriate measures to ensure that a child who is seeking refugee status or who is considered a refugee in accordance with applicable international or domestic law and procedures shall, whether unaccompanied or accompanied by his parents or by any other person, receive appropriate protection and humanitarian assistance in the enjoyment of applicable rights set forth in the present principles and in other international human rights instruments to which the said States are Parties. $^{33}$

29 Insert recommended by the Manila Seminar. At the Tehran Meeting of Experts, one participant suggested substituting "as regards" for "with due regard". No explanation was given. Another proposed substituting "international human rights conventions" for "generally accepted international instruments". One participant in the Meeting of Experts complained that refugees were sometimes given a higher standard of treatment than nationals. Another doubted this, pointing out that the rules of operation were precisely not to give the refugees higher treatment than the locals. On the contrary: the services made available to refugees in a given area are often extended, as necessary, to internally displaced persons and the local population as well.

${ }^{30}$ As this is a restatement of para.2 of this Art.VI, it had to be rephrased accordingly.

31 Derived from Art.IV of the OAU Convention and Art.3 (partially) of the 1951 Convention. The grounds of "ethnic origin" and "gender" are added to reflect current international standards, the latter reflecting Art.18 of the Vienna Declaration on Human Rights and foreshadowing the next paragraph. This clause reflects recommendation (d) of the Manila Seminar under "Points for Further Review".

${ }^{32}$ See para.(a) of UNHCR Executive Committee Conclusion No.64(XL1) on Refugee Women and International Protection. At the Tehran Meeting of Experts, during the discussion of a possible provision on women, children and elderly refugees, one participant proposed a general provision on vulnerable groups as an alternative to a separate one on each such group as in paragraphs 8 , 9 , and 10.

${ }^{33}$ Art.22(1) of the 1989 Convention on the Rights of the Child. 
8 States shall give special attention to the protection needs of elderly refugees to ensure not only their physical safety, but also the full exercise of their rights, including their right to family reunification. Special attention shall also be given to their assistance needs, including those relating to social welfare, health and housing.

\section{Article VIII: Expulsion and deportation}

1. Save in the national or public interest or in order to safeguard the population, ${ }^{34}$ the State shall not expel a refugee.

2. Before expelling a refugee, the State shall allow him a reasonable period within which to seek admission into another State. The State shall, however, have the right to apply during the period such internal measures as it may deem necessary and as applicable to aliens under such circumstances. ${ }^{35}$

3. A refugee shall not be deported or returned to a State or Country where his life or liberty would be threatened for reasons of race, colour, nationality, ethnic origin, ${ }^{36}$ religion, political opinion, ${ }^{37}$ or membership of a particular social group.

4. The expulsion of a refugee shall be only in pursuance of a decision reached in accordance with due process of law. Except where compelling reasons of national security otherwise require, the refugee shall be allowed to submit evidence to clear himself, and to appeal to and be represented for the purpose before competent authority or a person or persons specially designated by the competent authority. ${ }^{38}$

\footnotetext{
34 This excerpt is taken from Art.3(2) of the UN Declaration on Territorial Asylum. It substitutes for "on the ground of violation of the conditions of asylum". Another alternative proposed in Note (1) to Art.VIII of the Bangkok Principles would be:"save on ground of national security or public order, or a violation of the vital or fundamental conditions of asylum"; "national security and public order" are the only grounds provided for by the 1951 Convention in Art.32(1).

35 The phrase "as applicable to aliens under the same circumstances" is taken from Note (2) to Art.VIII.

${ }^{36}$ These additional grounds were recommended for the refugee definition by the Manila Seminar and the Tehran Meeting of Experts respectively. See footnote 2 above.

37 See footnote 3 above.

38 Art.32(2) of the 1951 Convention. This paragraph is consistent with the recommendation of a participant of the Tehran Meeting of Experts that a refugee should not be expelled without due process of law. It is also in conformity with Art.13 of the 1966 International Covenant on Civil and Political Rights. In the national context, the refugee's right to due process of law in expulsion cases was reaffirmed in the January 1996 decision of the Supreme Court of India in the case of National Human Rights Commission v. State of Arunachal Pradesh and Another (1996 (1) Supreme 295).
} 


\section{Durable Solutions}

\section{Article IV: Right of return}

1. A refugee shall have the right to return if he so chooses to the State of which he is a national or the Country of his nationality and in this event it shall be the duty of such a State or Country to receive him.

$2 .^{39} \quad$ This principle should apply to, inter alia, ${ }^{40}$ any person who because of foreign domination, external aggression or occupation has left his habitual place of residence or who ${ }^{41}$ being outside such place desires to return thereto.

3. It shall ... be the duty of the Government or authorities in control of such place of habitual residence to facilitate, by all means at their disposal, the return of all such persons as are referred to in the foregoing paragraph, and the restitution of their property to them. ${ }^{42}$

4. This natural right of return shall also be enjoyed and facilitated to the same extent as stated above in respect of the dependants of all such persons as are referred to in paragraph $\mathrm{I}^{43}$ above. ${ }^{44}$

\section{Article V: Right to compensation}

1. A refugee shall have the right to receive compensation from the State or the Country which he left or to which he was unable to return. ${ }^{45}$

2. The compensation referred to in paragraph 1 shall be for such loss as bodily injury, deprivation of personal liberty in denial of human rights, death of the refugee or the person whose dependant the refugee was, and destruction of or damage to property and assets, caused by the authority of the State or Country, public officials or mob violence.

3. ${ }^{46}$ Where such person does not desire to return, he shall be entitled to prompt and full compensation by the Government or the authorities in control of such place of habitual residence as determined, in the absence of agreement by the parties

39 This and the next two paragraphs are paras. (1), (2) and (3) of the 1970 Addendum to the Bangkok Principles. The incorporation of this Addendum was understood as appropriate in both Manila and Tehran.

40 Stylistic addition.

41 Idem.

421970 Addendum, para.2.

43 Modified due to change in paragraph numbering.

441970 Addendum, para.3.

45 While a Tehran Meeting of Experts participant called compensation a utopia, another called attention to its necessity when, for example, refugees' property has been confiscated. He was probably referring to historical cases of compensation and restitution from Germany and from Uganda.

46 This paragraph and the next are paras. (4) and (5) of the 1970 Addendum. See footnote 37 above for explanation. 
concerned, by an international body designated or constituted for the purpose by the Secretary-General of the United Nations at the request of either party.

4. If the status of such a person is disputed by the Government or the authorities in control of such a place of habitual residence, or if any other dispute arises, such matter shall also be determined, in the absence of agreement by the parties concerned, by an international body designated or constituted as specified in paragraph $(3)^{47}$ above. $^{48}$

\section{Article V(A): ${ }^{49}$ Voluntary repatriation ${ }^{50}$}

1. The essentially voluntary character of repatriation shall be respected in all cases and no refugee shall be repatriated against his will.

2. The country of asylum, in collaboration with the country of origin, shall make adequate arrangements for the safe return of refugees who request repatriation.

3. The country of origin, on receiving back refugees, shall facilitate their resettlement and grant them the full rights and privileges of nationals of the country, and subject them to the same obligations.

4. Refugees who voluntarily return to their country shall in no way be penalized for having left it or for any of the reasons giving rise to refugee situations. Whenever necessary, an appeal shall be made through national information media and through the relevant universal and regional organizations ${ }^{51}$ inviting refugees to return home without risk and to take up a normal peaceful life without fear of being disturbed and punished, and that the text of such appeal should be given to refugees and clearly explained to them by their country of asylum.

5. Refugees who freely decide to return to their homeland, as a result of such assurances or on their own initiative, shall be given every possible assistance by the country of asylum, the country of origin, voluntary agencies, and international and inter-governmental organizations to facilitate their return. ${ }^{52}$

\footnotetext{
47 Numbering modified according to the new numbering of the paragraphs.

481970 Addendum, para.5.

49 Under "Durable Solutions" the Manila Seminar made detailed recommendations on voluntary repatriation which are reflected in this new Article taken from the OAU Convention.

${ }^{50}$ Art.V of the OAU Convention. Similar provisions are found in UNHCR's EXCOM Conclusion No.40 (XXXVI) Voluntary Repatriation.

51 This phrase is substituted for "the Administrative Secretary-General of the OAU".

52 This and the other paragraphs of this proposed Article should meet the requirements of the Tehran Meeting of Experts participants who called for "ways and means to facilitate return", for "the means of integration after return", and for "sustainable reintegration".
} 


\section{Article V(B): ${ }^{53}$ Other solutions}

$1 .^{54}$ Voluntary repatriation, local settlement or resettlement, that is, the traditional solutions, all remain viable and important responses to refugee situations, even while voluntary repatriation is the pre-eminent solution. To this effect, States should undertake, with the help of international governmental and non-governmental organizations, ${ }^{55}$ development measures which would underpin and broaden the acceptance of the three traditional durable solutions.

2. States shall promote comprehensive approaches, including a mix of solutions involving all concerned States and relevant international organizations in the search for, and implementation of, durable solutions to refugee problems. ${ }^{56}$

3. The issue ${ }^{57}$ of $\operatorname{root}^{58}$ causes is crucial for solutions and international efforts should also be directed to the removal of the causes of refugee movements ${ }^{59}$ and the creation of the political, economic, social, humanitarian and environmental conditions conducive to voluntary repatriation. ${ }^{60}$

\section{Burden Sharing}

\section{Article IX ${ }^{61}$}

1. The refugee phenomenon continues to be a matter of global concern and needs the support of the international community as a whole for its solution and as such the principle of burden sharing should be viewed in that context.

53 While the Manila Seminar expressed the sense that the international climate was not ripe for a formal inclusion of local integration as a solution, it conceded that it had provided some positive experiences. As for third country resettlement, while the Seminar deemed it not a solution for the vast majority of refugees in the Afro-Asian region, it nevertheless agreed that the resettlement option needed to be left open (Report of the Seminar, p.6.) At the Tehran Meeting of Experts, both views were expressed and several participants called attention to the need to preserve these three traditional solutions in the light of positive experiences in specific refugee contexts. This proposed Article reflects these views.

${ }^{54}$ UNHCR's EXCOM Conclusion No. 61(XLI) Note on International Protection, paras. (iv) and (v).

5s Stylistic insertion.

56 Manila Seminar (see Report of the Seminar, p.6). At the Tehran Meeting of Experts, one participant recommended the consideration of "regional approaches", which in fact are not at all excluded from the concept of "comprehensive approaches".

57 The word "issue" is substituted for "aspect" for stylistic purposes.

58 The word "root" is added to the text in order better to reflect the recommendation made at the Tehran Meeting of Experts.

59 UNHCR's EXCOM Conclusion No. 40 (XXXVI), para. (c).

${ }^{60}$ Addressing the root causes of refugee movements by ensuring "sustainable repatriation" was recommended at the Tehran Meeting of Experts.

${ }^{61}$ The Manila Seminar recommended that paras. I to IV of the 1987 Addendum be incorporated into the Bangkok Principles under the heading of "Burden Sharing" and become a new Art.IX. 
2. The principle of international solidarity and burden sharing needs to be applied progressively to facilitate the process of durable solutions for (...) refugees, whether within or outside a particular region, keeping in perspective that durable solutions in certain situations may need to be found by allowing access to refugees in Countries outside the region, due to political, social and economic considerations.

3. The principle of international solidarity and burden sharing should be seen as applying to all aspects of the refugee situation, including the development and strengthening of the standards of treatment of refugees, support to States in protecting and assisting refugees, the provision of durable solutions and the support of international bodies with responsibilities for the protection and assistance of refugees. 4. International solidarity and cooperation in burden sharing should be manifested whenever necessary, through effective concrete measures in support of States requiring assistance, whether through financial or material aid or through resettlement opportunities.

5. ${ }^{62} \quad$ In all circumstances the respect for fundamental humanitarian principles is an obligation for all members of the international community. Giving practical effect to the principle of international solidarity and burden sharing considerably facilitates States' fulfillment of their responsibilities in this regard.

\section{Additional Provisions ${ }^{63}$}

\section{Article X: ${ }^{64}$ Rights granted apart from these Principles ${ }^{65}$}

Nothing in these Articles shall be deemed to impair any higher rights and benefits granted or which may hereafter be granted by a State to refugees.

\section{Article XI: ${ }^{66}$ Cooperation with international organizations}

States shall cooperate with the Office of the United Nations High Commissioner for Refugees and, in the region of its mandate, with the United Nations Relief and Works Agency for Palestine Refugees in the Near East. ${ }^{67}$

\footnotetext{
62 This paragraph is added to ensure a more complete statement of the principle of burden sharing and arises out of the discussions at the Tehran Meeting of Experts.

${ }^{63}$ Title added for clarity.

${ }^{64}$ This is the former Art.IX. The Manila Seminar had recommended that a new Art.IX be inserted under the rubric "Burden Sharing", and that this text be renumbered Art.X.

${ }_{65}$ Title added for clarity.

${ }^{66}$ Under the heading of "Cooperation with international organizations", the Manila Seminar "expressed its appreciation to UNHCR as well as to UNRWA for their dedication to their duties on behalf of refugees". (Report of the Seminar, p.5.)

${ }^{67}$ On cooperation with UNHCR, see Art. VIII (1) of the OAU Convention, Art.35 of the 1951 Convention, and Art.II of the 1967 Protocol relating to the Status of Refugees.
} 
B. Secretariat Study: BACKGROUND NOTE ON THE EXTRA-TERRITORIAL APPLICATION OF NATIONAL LEGISLATION: SANCTIONS IMPOSED AGAINST THIRD PARTIES, prepared for the Seminar held at Tehran on 24-25 January, 1998

It is recalled that a view had been expressed at the Thirty-sixth Session of the AALCC that the extraterritorial application of national legislation and sanctions against a third party is a violation of international law and that the AALCC, as a legal body of Asian-African countries, could have its own legal opinion on this issue. For this purpose, it was suggested that a comprehensive study concerning the legality of such unilateral measures may be considered by the Committee. ${ }^{68}$

The view was also expressed that an examination of the item by the Committee should be purely technical, based on legal analysis, and should not, to the extent possible, step into the political arena. The United Nations, the non-aligned forum and other fora could delve into the political dimension of the matter and the AALCC should not duplicate their work. The work of the AALCC, it was emphasized, required a different type of perspective to deal with this issue and that is the reason that a seminar of a group of experts from Member and non-Member States of the AALCC had been convened.

\section{THE IRAN AND LIBYA SANCTIONS ACT OF 1996: AN OVERVIEW}

In 1996, two legislations by the United States Congress extended the jursdiction of that Sstate beyond its territory, by imposing sanctions against third States that invest in, or enter into business with, Iran, Libya, and Cuba. First, in March 1996, the Cuban Liberty and Democratic Solidarity Act of 1996 (generally known by the names of its principal co-sponsors as the Helms-Burton Act) ${ }^{69}$ was signed by the United States President. The Act, inter alia, codifies the existing economic sanctions previously imposed against Cuba pursuant to executive orders. Again, on 5 August 1996, the United States President signed the Iran-Libya Sanctions Act of 1996 (generally known as the D'Amato-Kennedy Act), imposing sanctions against foreign companies that make investments which contribute to Iran's ability to develop its petroleum resources.

The Preamble to the Iran and Libya Sanctions Act of 1996 (hereinafter called "the Act") describes it as an Act to "impose sanctions on persons making investments

\footnotetext{
${ }^{68}$ It was also proposed that the AALCC should keep this issue under review and could support the inclusion of the item Extraterritorial Application of National Laws, or Unilateral Acts and their Legal Effects in the future program of the work of the International Law Commission. See the statement of the Delegate of the People's Republic of China made during the Fourth Plenary Meeting in the Verbatim Record of Discussions of the Thirty-sixth Session of the Asian-African Legal Consultative Committee, Tehran, May 1997.

${ }^{69}$ For the full text of the Cuban Liberty and Democratic Solidarity (LIBERTAD) Act, see 35 International Legal Materials (1996) p.397.
} 
directly and significantly contributing to the enhancement of the ability of Iran or Libya to develop its petroleum resources, and on persons exporting certain items that enhance Libya's weapons or aviation capabilities, or enhance Libya's ability to develop its petroleum resources, and for other purposes". ${ }^{70}$

In a memorandum circulated at the Fifty-first Session of the General Assembly the United States maintained that the Act will help to deprive both the Islamic Republic of Iran and the Libyan Arab Jamahiriya from a source of income which, it claimed, could be used to finance international terrorism and procure weapons of mass destruction. The memorandum had affirmed that with the Kennedy-D'Amato Law, it aimed to put pressure on Libya to comply with Security Council resolutions.

The Act defines both Iran and Libya in identical terms as "including any agency or instrumentality" of Iran or Libya. It requires persons both natural or legal, associations of persons, [and] governmental and non-governmental agencies to refrain from investing in either Iran or Libya any amount greater than US \$ 40 million during a twelve-month period. To that end the Act defines the term "investment" to mean:

(i) The entry into a contract that includes responsibility for the development of petroleum resources located in Iran or Libya or the entry into a contract providing for the general supervision and guarantee of another person's performance of such a contract.

(ii) The purchase of a share of ownership, including an equity interest, in that development.

(iii) The entry into a contract providing for the participation in royalties, earnings or profits in that development, without regard to the form of participation. The term 'investment' does not include the entry into, performance, or financing of a contract to sell or purchase goods, services, or technology. ${ }^{71}$

It may be stated that the investments under contracts existing prior to 5 August 1996 are beyond the pale of the Act and are exempted. The term "petroleum resources" is to have a large connotation and includes petroleum and natural gas resources.

Section 3 of the Act sets out the Declaration of Policy. Paragraph (a) of Section 3 called "Policy with Respect to Iran" reads:

"The Congress declares that it is the policy of the United States to deny Iran the ability to support acts of international terrorism and to fund the development and acquisition of weapons of mass destruction and the means to deliver them by limiting the development of Iran's ability to explore for, extract, refine, or transport by pipeline

70 See text of the Iran and Libya Sanctions Act, 1996.

71 See Section 14(9) of the Iran and Libya Sanctions Act, 1996 
petroleum resources of Iran. ${ }^{72}$ This Declaration of Policy with respect to Iran is based on the Congress findings as set out in Section 2 of the Act."

To further the objectives of the Act Section 4, inter alia, urges the President of the United States to "commence immediately diplomatic efforts, both in appropriate international fora such as the United Nations, and bilaterally with allies of the United States, to establish a multilateral sanctions regime against Iran, including provisions limiting the development of petroleum resources that will inhibit Iran's efforts" to carry out activities described in Section 2 of the Act.

Section 4 of the Act entitled "Multilateral Regimes", it has been suggested, "provides for the integration of coercive economic measures into multilateral systems." ${ }^{, 73}$ Section 4(e) of the Act required the President to present an interim report monitoring multilateral sanctions, not later than 90 days after the enactment of the Act, to the Appropriate Congressional Committee ${ }^{74}$ on:

(1) whether the member States of the European Union, the Republic of Korea, Australia, Israel or Japan have legislative or administrative standards providing for the imposition of trade sanctions on persons or their affiliates doing business or having investments in Iran or Libya:

(2) the extent and duration of each instance of the applications of such sanctions; and

(3) the disposition of any decision with respect to such sanctions by the World Trade Organization or its predecessor organization. ${ }^{75}$

The President is thereafter to report to the "appropriate congressional committees" on the extent that diplomatic efforts, referred to above, have been successful. Each report is to include (i) the countries that have agreed to undertake measures to further the policy objectives with respect to Iran, together with a description of those measures; and (ii) the countries that have not agreed to undertake measures.

\footnotetext{
72 The Policy with Respect to Libya is set out in paragraph (b) of the same section in the following terms: "The Congress further declares that it is the policy of the United States to seek full compliance by Libya with its obligations under Resolutions 731, 748, and 883 of the Security Council of the United Nations, including ending all support for acts of international terrorism and efforts to develop or acquire weapons of mass destruction".

${ }^{73}$ See the statement of the Representative of Iraq at the Sixty-seventh Plenary Meeting of the Fiftyfirst Session of the General Assembly.

${ }^{74}$ Section 14(2) of the Act defines the term "Appropriate Congressional Committee" to mean the Committee on Finance, the Committee on Banking, Housing, and Urban Affairs, and the Committee on Foreign Relations of the Senate and the Committee on Ways and Means, the Committee on Banking and Financial Services, and the Committee on International Relations of the House of Representatives.

75 Section 4(e) of the Act.
} 


\section{A. Sanctions}

Section 6 of the Act called the Description of Sanctions stipulates that the sanctions to be imposed on a sanctioned person are:

1. Export-Import Bank assistance for exports to sanctioned persons;

2. Export sanction;

3. Loans from financial institutions;

4. Prohibitions on financial institutions;

5. Procurement sanction; and

6. Additional sanction.

\section{Export-Import Bank assistance for exports to sanctioned persons}

Under Section 6 paragraph 1 the President may direct the Export-Import Bank of the United States not to give approval to the issuance of any guarantee, insurance, extension of credit, or participation in the extension of credit in connection with export of any goods or services to any sanctioned person.

\section{Export sanction}

Section 6 paragraph 2 stipulates that the President may order the United States Government not to issue any specific licence and not to grant any other specific permission or authority to export any goods or technology to a sanctioned person under (i) the Export Administration Act of 1979; (ii) the Arms Export Control Act; (iii) the Atomic Energy Act of 1954; or (iv) any other statute that requires the prior review and approval of the United States Government as a condition for the export or re-export of goods or services.

\section{Loans from financial institutions}

Pursuant to Section 6(3) of the Act the United States Government may prohibit any United States financial institution from making loans or providing credits to any sanctioned person totalling more than US $\$ 10,000,000$ in any 12-month period unless such person is engaged in activities to relieve human suffering and the loans or credits are provided for such activities.

\section{Prohibitions on financial institutions}

It may be stated at this juncture that under the Act the term "financial institution" includes (a) a depository institution ${ }^{76}$ including a branch or agency of a foreign bank; $;^{77}$ (b) a credit union; (c) a securities firm, including a broker or dealer; (d) an insurance company, including an agency or underwriter, and (e) any other company that provides financial services.

Paragraph 4 of Section 6 of the Act envisages two kinds of prohibitions that may be imposed against a sanctioned person that is a financial institution. These are: (a)

\footnotetext{
76 As defined in Section 3 (c)(1) of the Federal Deposit Insurance Act.
}

77 As defined in Section 1(b)(7) of the International Banking Act, 1978. 
Prohibition on Designation as Primary Dealer; and (b)Prohibition on Service as a Repository of Government Funds.

As regards the prohibition on designation as primary dealer it is stipulated that neither the Board of Governors of the Federal Reserve System nor the Federal Reserve Bank of New York may designate, or permit the continuation of any prior designation of, such financial institution as a primary dealer in United States Government debt instruments.

As to the prohibition on service as a Repository of Government Funds it is stipulated that a financial institution may not serve as an agent of the United States Government or serve as repository for United States Government funds.

The subsection goes on to clarify that the imposition of either prohibition on a sanctioned person that is a financial institution shall be treated as a single sanction and that the imposition of both shall be treated as two sanctions for the purposes of Section 5 of the Act.

\section{Procurement sanction}

The United States Government may not procure, or enter into any contract for the procurement of, any goods or services from a sanctioned person.

\section{Additional sanction}

Finally, the President may, in accordance with the International Emergency Economic Powers Act, impose sanctions to restrict imports with respect to a sanctioned person.

The European Union has identified the measures taken by the United States President to limit imports into [the] USA, prohibition of designation as primary dealer or as repository of USA Government funds, denial of access to loans from USA institutions, export restrictions by [the] USA, or refusal of assistance by the ExportImport Bank, as damaging to its interests.

$\mathrm{Be}$ that as it may, the impermissibility under international law of unilateral sanctions is uniformly recognized by the international community. The adoption of coercive economic measures lies only within the mandate of the United Nations in particular instances where there exists a threat to peace or breach of peace.

\section{B. Ratione personae}

The ratione personae of the Act is set out in Section 5(e) which identifies the Persons Against Which the Sanctions Are to be Imposed. The sanctions described in the Act are to be imposed on (i) any person [who] the President determines has carried out the activities described; (ii) [a] successor entity to the person referred [to]; (iii) a parent or subsidiary of that person, if that parent or subsidiary, with actual knowledge, engaged in the activities referred to; (iv) or an affiliate if that affiliate, with actual knowledge, engaged in those activities and if the affiliate is in fact controlled by the person.

Section 14 paragraph 14 stipulates that the term 'person' means (a) a natural person; (b) a corporation business association, partnership, society, trust, any other 
non-governmental entity, organization, or group, and any other governmental entity operating as a business enterprise; and (c) any successor to any entity described above.

\section{Ratione temporis}

The Iran and Libya Sanctions Act of 1996 entered into force on the date of its enactment, viz. 5 August 1996. It will "cease to be effective five years after the date of the enactment of the Act".

The Iran-Libya Sanctions Act goes beyond previous sanctions imposed by the United States against other States and is not limited to regulating American interests in these countries. Rather, like the LIBERTAD Act it is designed to impose sanctions on companies or individuals located outside the United States that trade with Iran and Libya, and these sanctions are targeted at investments of non-US businesses in the oil industries of Iran and Libya, i.e. investments having no necessary link with the United States.

In the course of the debate at the Thirty-sixth Session of the AALCC it was pointed out that the imposition of sanctions is permissible only by the United Nations under Chapter VII of the Charter. Article 41 of the United Nations Charter provides, inter alia, for "complete or partial interruption of economic relations" in order to give effect to Security Council decisions with respect to maintaining or restoring international peace and security. Sanctions can only be imposed by the Security Council against a law-breaking State after the determination of the existence of [a] "threat to peace, breach of peace or act of aggression". The Security Council has followed this procedure over the past half a century. Although the sanctions policies of the United Nations remain under criticism, the power of the United Nations to enforce sanctions and the obligation of the Member States to abide by such decisions continue to remain as part and parcel of contemporary international law.

The General Assembly on its part has 1epeatedly denounced economic coercion as a means of achieving political goals. Among these the resolution entitled "Economic Measures as a means of Political and Economic Coercion against Developing Countries" has strongly urged the industrial nations to abstain from the use of their superior position as a means of applying economic pressure "with the purpose of inducing changes in the economic, political, commercial and social policies of other countries."

The unilateral imposition of sanctions infringes upon the right to development. The Vienna Declaration and Programme of Action of 25 June 1993 has delineated that the Right to Development has become a "universal and inalienable right and an integral part of fundamental human rights."78 The Declaration on the Right to Development describes this principle as "an inalienable right by virtue of which every human person and all peoples are entitled to participate in, contribute to, and enjoy economic, social, cultural and political development, in which all human rights and fundamental freedoms can be fully realized."79

${ }^{78}$ Op.cit.note 9 [Ed.: referring to the numbering in the original document, not reproduced here].

79 See Art. 1 paragraph 1 of General Assembly Resolution 41/128 of 4 December 1986. 
Another inherent flaw is that the unilateral imposition of sanctions violates the principle of non-intervention. The principle of non-intervention, a customary norm of international law, is backed by established and substantial state practice and has been incorporated in various internationally binding instruments as well as the General Assembly resolutions. The resolutions of the General Assembly and the proceedings of the International Court of Justice ${ }^{80}$ provide ample evidence that the non-intervention principle encompasses the rejection of intervention and interference in both internal and external affairs of other States. Consequently, imposition of secondary sanctions, which interrupt economic cooperation and trade relations of target States with third parties, violates the universally accepted principle of non-intervention in the international [sic; internal?] and external affairs of other States.

\section{GENERAL ASSEMBLY OF THE UNITED NATIONS}

An item entitled "Elimination of Coercive Economic Measures as a Means of Political and Economic Compulsion" was inscribed on the agenda of the Fifty-first Session of the General Assembly at the request of the Libyan Arab Jamahiriya. In the course of deliberations on the item it was pointed out that the United States had enacted legislation that punishes foreign non-United States companies which invested more than US \$40 million to develop petroleum resources in either the Islamic Republic of Iran or the Libyan Arab Jamahiriya. It was recalled that the United States had often employed sanctions to bring pressure what it termed "rogue" States. ${ }^{81}$

The enactment of laws which contravene the principle of territoriality [of] national laws significantly affects the sovereignty of other States and the legitimate interests of companies and persons within their jurisdiction.

The view was expressed that on the threshold of the new millennium, the emergence of unilateral coercive measures of an extraterritorial nature entails yet another serious danger in the context of an increasingly interdependent world. The risks posed by a country in unilaterally reserving the right to undermine the discipline of multilateral trade for reasons totally alien to trade issues must be confronted appropriately and resisted by the international community.

In the course of the debate on the item it was, inter alia, pointed out that the imposition of coercive measures and the approval of domestic legislation for the horizontal escalation of such actions with extraterritorial implications contradicts

\footnotetext{
${ }^{80}$ The International Court of Justice in the Case concerning the Military and Paramilitary Activities in Nicaragua against the United States of America has established that: "The principle of nonintervention established the right of every sovereign State to rule its affairs without foreign interference; although examples of violation of such principle are not rare, the Tribunal states that it is part of the customary international right [sic]. The existence of the Non-intervention principle is backed by a very important and well-established practice. On the other hand, this principle has been introduced as corollaries [sic] of sovereign equality of all States".

${ }^{81}$ The United States of America has since 1941, either unilaterally or in concert with others, invoked sanctions more than 70 times. The overall success of sanctions has largely been limited. For details see The Wall Street Journal 25 November 1996.
} 
established international trade law including the regulations of the World Trade Organization. $^{82}$

Speaking on behalf of the European Community at the Fifty-first Session of the General Assembly, the Permanent Representative of Ireland stated: "the European Union wishes to reiterate its rejection of attempts to apply national legislation on an extra-territorial basis." He concluded: "Measures of this type violate the general principles of international law and the sovereignty of independent States."

At that session the Assembly by its Resolution 51/22 of 27 November 1996, guided by the principles of the Charter of the United Nations, particularly those which call for the development of friendly relations among nations, and the achievement of cooperation in solving problems of an economic and social character, recalled its resolutions in which it had called upon the international community to take urgent and effective steps to end coercive economic measures. ${ }^{83}$ Concerned over the enactment of extraterritorial coercive economic laws in contravention of the norms of international law and believing that the prompt elimination of such measures is consistent with the aims and purposes of the United Nations and the relevant provisions of the World Trade Organization, the General Assembly reaffirmed the "inalienable right of every State to economic and social development and to choose the political, economic and social system which it deems most appropriate for the welfare of its people in accordance with its national plans and policies," and called for "the immediate repeal of unilateral extraterritorial laws that imposed sanctions on companies and nationals of other States". It also called upon all States not to recognize unilateral extraterritorial coercive economic measures or legislative acts imposed by any State, ${ }^{84}$ and decided to include in the agenda of its Fifty-second session an item entitled "Elimination of Coercive Economic Measures as a Means of Political and Economic Coercion."

By its Resolution 51/22 the General Assembly had requested the Secretary-General to prepare a report on the implementation of the resolution in the light of the purposes and principles of the Charter of the United Nations and international law, and to submit the same to the Assembly at its Fifty-second Session. Pursuant to that request the Secretary-General invited Governments to furnish any information that they may wish to contribute to the preparation of that report. In response to that invitation of

\footnotetext{
82 The Understanding of Rules and Procedures Governing Settlement of Disputes, adopted as an Annex to the Agreement Establishing the World Trade Organization (WTO), inter alia incorporates restrictions on the use of individual counter measures. A similar provision can also be found in the North American Free Trade Agreement (NAFTA).

${ }^{83}$ See Resolutions 47/19, 48/16, and 49/9 of the General Assembly of the United Nations. A similar resolution, calling upon all States to refrain from promulgating laws and regula-

tions the extraterritorial effects of which affect the sovereignty of other States, the legitimate interests of entities or persons under their jurisdiction and the freedom of trade and navigation, was also adopted at the Fiftieth Session of the General Assembly.

${ }^{84}$ Earlier by its Resolutions $47 / 19$ and 50/10, the General Assembly had called upon all States to refrain from promulgating and applying such laws and measures in conformity with their obligations under the Charter of the United Nations and international law which, inter alia, reaffirm the freedom of trade and navigation. These resolutions call upon States to revoke such laws.
} 
the Secretary-General, the Government of Belgium stated that, like its partners in the European Union, it was "opposed to the extraterritorial application of national legislation, more particularly the unilateral imposition of commercial measures, especially sanctions." ${ }^{.85}$ The Government of Iraq in its reply to the Secretary-General stated, inter alia, that the coercive measures taken by some States constitute a real threat to international peace and security, and a flagrant violation of human rights principles. It went on to suggest that "the international community, as represented by the United Nations, must increase the resolute and effective measures it takes with a view to dissuading States from taking such action and in order to block any attempts to apply pressure on the United Nations or any multilateral body, or to use them as a means to legitimize such practices, which conflict with the Provisions and Precepts of international law." ${ }^{86}$

The Government of the Islamic Republic of Iran observed that the "consideration of this very issue in all recent major international conferences and summits is a manifestation of the international concern about the multidimensional character of unilateral coercive economic measures which adversely affect all countries and the world economy as a whole".

The outcome of the debate, during the recently concluded Fifty-second Session of the General Assembly, at the time of preparing this Background Note was not available to the Secretariat.

\section{EUROPEAN ECONOMIC COMMUNITY}

The European Economic Community too asserts an extraterritorial application of its own competition laws and the application of these rules to international trade and economic relations has been equally controversial. As regards the European Community it has been stated that "(i) legislative jurisdiction may not be extended to acts outside Community territory in so far as prohibitive rules of international law stand in the way of such extension; (ii) enforcement jurisdiction is strictly limited to Community territory, unless the rules of international law permit an extension to the territory of third States." 87

Be that as it may, it has been and continues to be the policy of the European Union to oppose national legislation with extra-territorial effects. The 1982 Amendments to the US Export Administration Regulations which expanded the US's control on the export and re-export of goods and technical data to [the] USSR, was objected to by the European Commission. The European Commission called these amendments "unacceptable under international law because of their extra-territorial effects."

\footnotetext{
${ }^{85}$ It went on to state that the European Union had confirmed this position in its explanation of the vote when the General Assembly voted on Resolution 51/22. See Elimination of coercive economic measures as a means of political and economic compulsion. Report of the SecretaryGeneral, A/52/343, 15 September 1997.

${ }^{86}$ Ibid.

87 P.J.KUYPER, "European Community Law and Extra-territoriality: Some Trends and New Developments' in 33 ICLQ (1984) p.1013.
} 
The European Union strongly opposed the enactment of the legislation and termed the extraterritorial application of US jurisdiction baseless in international law. The essence of the European objection to the [Kennedy-]D'Amato Act is summarized in the following extract from a letter addressed by [the] EU to Senator D'Amato on 12 February 1996:

"We find it unacceptable that companies incorporated in and operating from [the] European Community will be threatened by unilateral US sanctions when maintaining legitimate business relations with Iran and Libya. We reiterate our opposition that the US has no basis in international law to claim the right to regulate in any way transactions taking place outside the US."

The European Union's démarches protesting the Cuban Liberty and Democratic Solidarity (Libertad) Act of 15 March 1995 had, inter alia, pointed out that the European Union had consistently expressed its opposition as a matter of law and policy to extra-territorial application of US jurisdiction, which would restrict European Union trade in goods and services with Cuba. It emphasizes that "it cannot accept US unilateral determination and restrict EU economic and trade relations with third countries." 88 The Council of Ministers of the European Union adopted a regulation declaring the Act to be in violation of international law and decreeing that any company established in Europe that is subjected to a judgment under the Act may "claw back" against the assets of the American plaintiff in any of the Union's States.

The Council of the European Union has by its Regulation No. 2271/96 of 22 November 1996 emphasized that extraterritorial application of laws, regulations, and other legislative instruments which purport to regulate activities of natural and legal persons under the jurisdiction of its Member States violate international law and impede the attainment of the objective of free movement of capital between its Member States and third countries. It further states that such laws, regulations and other legislative instruments, which by their extra-territorial application purport to regulate activities of natural and legal persons, "affect or are likely to affect the established legal order and have adverse effects on the interests of the Community and the interests of natural and legal persons exercising rights under the Treaty establishing the European Community."

Article 1 of the Regulation adopted by the European Council provides protection against and counteracts the effects of extraterritorial application of the (i) National Defense Authorization Act for Fiscal Year 1973, Title XVII "Cuban Democracy Act 1992"; (ii) Cuban Liberty and Democratic Solidarity Act of 1996; (iii) Iran and Libya Act of 1996, and (iv) Code of Federal Regulations Chapter V (7.1.95 edition) Part

${ }^{88}$ See the text of the European Union Demarches Protesting the Cuban Liberty and Democratic Solidarity (Libertad) Act in 35 International Legal Materials (1996) p.397. 
515 - Cuban Assets Control Regulations, subparts B (Prohibitions), E (Licenses, Authorizations and Statements of Licensing Policy) and G (Penalties) ${ }^{89}$

\section{GROUP OF 77}

The Ministerial Declaration of the Group of 77 adopted at Midrand, South Africa, on 28 April 1996 during the Ninth Session of the UNCTAD, inter alia observed that although the Uruguay Round Agreements and the establishment of the World Trade Organization (WTO) had boosted confidence in the multilateral trading system, its credibility and sustainability are being threatened by emerging recourse to unilateral and extra-territorial measures. The Declaration emphasized that environmental and social conditionalities should not constitute new obstacles to market access for developing countries. That Declaration had also expressed concern at the "continuing use of coercive economic measures against developing countries through, inter alia, unilateral economic and trade sanctions which are in clear contradiction with international law." ${ }^{90}$

The Group of 77 had at Midrand objected to the new attempts aimed at extraterritorial application of domestic law, which "constitutes a flagrant violation of the United Nations Charter and of WTO rules."

\section{NON-ALIGNED COUNTRIES}

The Eleventh Conference of the Heads of State or Government of the NonAligned Countries held in Cartagena de Indias, Colombia, in October 1995 had, inter alia, "condemned the fact that certain countries, using their predominant position in the world economy, continue to intensify their coercive measures against developing countries, which are in clear contradiction with international law, such as trade restrictions, blockades, embargoes and freezing of assets with the purpose of preventing these countries from exercising their right to fully determine their political, economic and social systems and freely expand their international trade. They deemed such measures unacceptable and called for their immediate cessation."

The Eleventh Conference of the Heads of State or Government of the NonAligned Countries had called upon the developed countries "to put an end to all political conditionalities to international trade, development assistance and investment, as they are fully in contradiction with the universal principles of self-determination, national sovereignty and non-interference in internal affairs."

The Eleventh Conference of the Heads of State or Government of the NonAligned Countries had also called upon the Government of the United States of

\footnotetext{
${ }^{89}$ For the full text of the European Council: Regulation (EC) No. 2271/96, Protection Against the Effects of the Extraterritorial Application of Legislation Adopted by a Third Country of 22 November 1996, see 36 International Legal Materials (1997) p.125.

90 See the Ministerial Declaration of the Group of 77, Midrand, South Africa, 28 April 1996, in the Report of the United Nations Conference on Trade and Development on its Ninth Session, Midrand, South Africa, 27 April-11 May 1996. Doc.TD/378 p.89 at 90.
} 
America to "put an end to the economic, commercial and financial measures and actions which in addition to being unilateral and contrary to the Charter and international law, and to the principles of neighbourliness, cause huge material losses and economic damage."

More recently, the Twelfth Conference of the Foreign Ministers of the NonAligned Countries held in New Delhi in April 1997, inter alia, called upon all States to refrain from adopting or implementing extra-territorial or unilateral measures of coercion as means of exerting pressure on non-aligned and developing countries. They noted that measures such as Helms-Burton and Kennedy-D'Amato Acts constitute violations of international law and the Charter of the United Nations, and called upon the international community to take effective action in order to arrest this trend.

\section{ORGANIZATION OF ISLAMIC CONFERENCE}

Like the Non-Aligned Movement, the Organization of [the] Islamic Conference (OIC) has rejected extra-territorial application of domestic law as illegal and unacceptable. The Preparatory Meeting for the Twenty-fourth OIC Ministerial Conference adopted a similar position. The Eighth Islamic Summit Conference held in Tehran in December 1997 declared its firm commitment to the rejection of unilateral and extra-territorial law. The Final Declaration of the Eighth OIC Summit held in Tehran, inter alia, rejected unequivocally the "unilateralism and extra-territorial application of domestic law" and urged all States to "consider the so-called D' Amato Act as null and void."

\section{THE IBER-AMERICAN SUMMIT CONFERENCE}

In November 1996, leaders of Latin America, Spain and Portugal denounced the sanctions as violating international law at [the] Iber-American Summit Conference held in Chile. The resolution of the Conference was based on the opinion of the InterAmerican Juridical Committee. In its opinion of 23 August 1996 [the] Inter-American Juridical Committee had, inter alia, observed that:

\footnotetext{
"Except where a norm of international law permits, the State may not exercise its power in any form in the territory of another State. The basic premise under international law for establishing legislative and judicial jurisdiction is rooted in the principle of territoriality."91
}

91 See the Opinion of the Inter-American Juridical Committee in Response to Resolution AG/ DOC.3375/96 of the General Assembly of the organization, entitled 'Freedom of Trade and Investment in the Hemisphere' in 35 International Legal Materials (1996) p.1329 at 1333. 
B annex: Report of the Rapporteur Dr.V.S. Mani on the Seminar on Extraterritorial Application of National Legislation: Sanctions Imposed Against Third Parties, Tehran, 24-25 January 1998

1. ...

\section{Introduction}

2. The Seminar was participated in by delegations from sixteen Member Countries of the AALCC, seven Observer delegates, and seven experts, three of whom are from non-Member Countries. One expert could not attend but sent his paper for the Seminar, while the seven experts who attended made presentations at the Seminar.

3. The present report seeks to portray an overview of the Seminar in terms of the major issues raised, broad areas of agreement, the few points of disagreement, State responses to unilateral sanctions imposed through extraterritorial application of national legislations, and the further work to be pursued in [the] study and elaboration of rules.

\section{The issues}

4. The deliberations at the Seminar focused on a range of legal and policy aspects of the subject mainly in relation to two US enactments, namely, the Helms-Burton Act, 1966 and the D'Amato Act, 1966, although references were also made to some of the earlier US laws such as the anti-trust legislation, the US Regulations Concerning Trade with [the] USSR, 1982, and the National Defence Authorization Act, 1991 (i.e. the Missile Technology Control Regime - MTCR - Law).

5. The legality of the two 1966 US enactments was examined in terms of their conformity with the peremptory norms of international law, the law relating to countermeasures, the law relating to international sanctions, principles of international trade law, the law of liability of States for injurious consequences of acts not prohibited by international law, [the] impact of unilateral sanctions on the basic human rights of the people of the target state, and issues of conflict of laws such as nonrecognition, forum non conveniens and other aspects of extraterritorial enforcement of national laws.

6. At least two of the presentations expounded the policy implications and foundations of the Helms-Burton Act and the D'Amato Act. They also analyzed the major provisions of these statutes [and] examined their international legal validity.

\section{Broad areas of agreement}

7. There was general agreement that the validity of any unilateral imposition of economic sanctions through extra-territorial application and [sic;of?] national legis- 
lation must be tested against the accepted norms and principles of international law. The principles discussed included those of sovereignty and territorial integrity, sovereign equality, non-intervention, self-determination, and the freedom of trade. It was generally agreed that the Helms-Burton Act and the D'Amato Act in many respects contravened these basic norms. The right to development and the permanent sovereignty over natural resources were specifically mentioned, and it was argued that the two enactments impinged on these principles as well.

8. While discussing the law relating to countermeasures, it was generally agreed that the rules of prohibited countermeasures as formulated by the International Law Commission in its draft articles on State Responsibility must apply to determine the legality of countermeasures purported to be effected by the extraterritorial application of the two impugned US statutes. These rules include the prohibition of injury to third States, the rule of proportionality, and also the other rules relating to prohibited countermeasures incorporated in Article 13 of the ILC draft articles.

9. While discussing countermeasures, it was emphasized that the presiding peremptory norm must be the peaceful settlement of disputes. All States have an obligation to seek settlement of their international disputes through peaceful means, an obligation to continue to seek such settlement, an obligation not to aggravate the dispute pending peaceful resolution, and an obligation not to resort to countermeasures until after all reasonably possible methods of peaceful settlement have failed.

10. The ensuing discussion also highlighted the interplay between countermeasures and non-intervention, and between countermeasures and unilateral imposition of economic sanctions.

11. There was also general agreement that countermeasures could not be a facade for unilateral imposition of sanctions in respect of matters that fell within the purview of Chapter VII of the Charter of the United Nations or the sanctions competence of other international organizations. A State could not take the law into its own hands where an organization had competence to decide whether or not sanctions should be issued. The differences between countermeasures and sanctions of the nature of international sanctions should be recognized, it was argued.

\section{Points of disagreement}

12. The Seminar revealed three main points of disagreement. First, whether the subject should be confined to secondary sanctions through extraterritorial application of national laws. There was a view held by an overwhelming majority of the participants that the delegate [sic] should encompass all legal aspects of unilateral economic sanctions imposed through extraterritorial application of national legislation. The reasons in support of this proposition were given at two levels. First, it was pointed out that some of the Member States were themselves targets for [sic] such legislation. Second, it was also contended, the distinction between the target State and the third State was often not maintainable in terms of the basic legality of the sanctioning 
legislation. The opposite view was that the subject should be confined in terms of the impact of unilateral sanctions on third States, since it was clearly identifiable and separable from the impact on the target State.

13. Second, there was also a disagreement on the distinction between the prescriptive jurisdiction and the enforcement jurisdiction of every State. A minority view argued that what mattered for State responsibility was violation of international law by a State under its enforcement jurisdiction. Passing a piece of domestic legislation, even if purported to be enforced but not yet enforced, in itself did not invite State responsibility. The majority view, however, was that a national legislature could also involve State responsibility, by directing action by national authorities. Also, even a threat of sanctions could cause injury to the economy of another State. At any rate, it was pointed out, the concept of reparation must wipe out all consequences of an illegal act, including its ultimate source.

14. Third, the debate revealed a further disagreement concerning the applicability of WTO disputes settlement procedure to resolve disputes relating to the HelmsBurton Act and the D'Amato Act in their extra-territorial application. One view was that the United States could, as it did, make its national security interests in defence of its unilateral action and that therefore the WTO fora would not have the jurisdiction to deal with the disputes. The contrary view was that the WTO Disputes Settlement Body and the Council had competence to interpret the provisions of the Agreements. The economic sanctions, according to this view, by definition invited the disputes settlement competence of WTO.

\section{$V$. State responses to unilateral sanctions through extra-territorial application of US national legislation}

15. The Seminar deliberations touched on a range of State responses to counter the possible impact of the US legislation in particular and the unilateral imposition of sanctions through extraterritorial application of domestic legislation in general. Detailed references were made to the response of the Inter-American System and the European Union. The measures discussed encompassed "blocking" legislation, statutes with 'drawback' provisions and laws providing for compensation claims, all at the national level. At the international level the responses noted included diplomatic protests, negotiations for exemptions, waivers in application of the projected sanctions, negotiations for settlement of disputes, use of WTO avenues, and measures to influence the drafting of legislation in order to prevent its adverse extraterritorial impact. It was also suggested, as a lego-political response, that an old agenda item calling [sic; called?] for a study of the distinction between acts in pursuance of the right of self-determination and terrorist acts. 


\section{Future work to be undertaken}

16. A number of proposals was made by the participants for [the] AALCC to pursue. The Rapporteur takes the liberty of reformulating some of them and adding some of his own.

17. The proposals would include formulation of principles, and sponsorship of studies.

\section{A. Formulation of principles/rules}

18. The Rapporteur proposes that:

(i) AALCC along with ILC undertake formulation of principles/rules relating to the extraterritorial application of national laws, in all its implications.

(ii) There is a need for a second look at the ILC formulation of principles concerning countermeasures vis-à-vis sanctions. The ILC formulation of countermeasures seems to leave this aspect open. A State may violate (a) an obligation erga omnes or (b) an obligation erga omnes but injuring another State, or (c) an obligation vis-à-vis another State: which of these situations would give rise to countermeasures? A clarification on this issue will help in determining the permissible countermeasures, and the relation between them and sanctions.

Similarly, the relationship between countermeasures and other peremptory norms of international law such as non-intervention and peaceful settlement of international disputes needs to be further examined.

\section{B. Proposals for studies}

19. It is also suggested that AALCC undertake three studies:

(i) A study on unilateral sanctions, countermeasures and disputes settlement procedures offered by the WTO group of agreements;

(ii) A study of the concept of abuse of rights in international law, preferably under the presiding norm of good faith, with[in the] context of exercised extraterritorial application of national laws in pursuit of national policy objectives; and

(iii) A study of the impact of unilateral sanctions on trade relations between States.

20. No doubt the above proposals, if approved by the Members of the AALCC, would require close cooperation of the Members with the AALCC Secretariat. 

C. Secretariat Study: WORLD TRADE ORGANIZATION: DISPUTE SETTLE-
MENT MECHANISM

\section{Overview of GATT practice}

\section{The Working of the WTO Dispute Settlement System since its Establishment:}

\section{A Survey}

Since the entry into force of the WTO Agreement on 1 January 1995, and until the end of August 1997, the DSB [Dispute Settlement Body] was notified of almost 100 requests for consultations pursuant to paragraph 4 of the WTO Dispute Settlement Understanding. In comparison with the GATT's dispute resolution mechanism (which dealt with some 300 disputes - an average of six disputes a year), the record of the WTO dispute settlement mechanism (averaging 40 disputes annually) has been hailed ... [as] represent[ing] a vote of confidence by WTO Members in the improved dispute settlement procedures of the new organization. This is part of the brief endeavours to provide a preliminary survey of the working with the WTO dispute settlement system since its establishment.

Adoption of reports by the DSB: The DSB, which is the final decision-making body on all disputes within the WTO framework, has adopted the following seven reports (covering the period between January 1995 ... [and] September 1997):

1. United States - Standards for Reformulated and Conventional Gasoline, complaints by Venezuela and Brazil. A single panel, established to consider both complaints, found the regulation to be inconsistent with GATT Article 111:4 and not to benefit from an Article XX Exception. Following an appeal by United States, the Appellate Body issued its report, modifying the panel report on the interpretation of GATT Article XX $(\mathrm{g})$, but concluding that the exception provided by Article XX was not applicable in this case. The Appellate Body Report, together with the panel report as modified by the Appellate Body Report, was adopted by the DSB on 20 May 1996.

2. Japan - Taxes on Alcoholic Beverages, complaints by the European Communities (EC), Canada and the United States. A joint panel was established by the DSB on 27 September 1995. The panel report found the Japanese tax system to be inconsistent with GATT Article 111:2. Following an appeal by Japan, the Appellate Body reaffirmed the panel's conclusion, but pointed out the areas where the panel had erred in its legal reasoning. The Appellate Body Report, together with the panel report as modified by the Appellate Body Report, was adopted by the DSB on 1 November 1996.

3. United States - Restrictions on Imports of Cotton and Man-made Fibre Underwear, complaint by Costa Rica. The panel found that the US restraints were not valid. 
On 11 November 1996, Costa Rica notified its decision to appeal against certain aspects of the panel report. The Appellate Body allowed the appeal. The Appellate Body Report, together with the panel report as modified by the Appellate Body Report, was adopted by the DSB on 25 February 1997. On 10 April 1997, the US informed the DSB that the measure had expired on 27 March 1997 and not renewed.

4. Brazil-Measure Affecting Desiccated Coconut, complaint by Philippines. The report of the panel concluded that the provisions of the agreements relied on by the claimant were inapplicable to the dispute. Following the appeal by Philippines, the Appellate Body upheld the findings of the panel. The Appellate Body Report, together with the panel report as upheld by the Appellate Body Report, was adopted by the DSB on 20 March 1997.

5. United States - Measures Affecting Imports of Woven Wool Shirts and Blouses, complaint by India. The panel established on 17 April 1996 found that the US safeguard measure violated the provisions of the Agreement on Textiles and Clothing, and the GATT 1994. On 24 February 1997, India notified its intention to appeal. The Appellate Body upheld the panel's decisions on those issues of law and legal interpretations that were appealed against. The Appellate Body Report, together with the panel report as upheld by the Appellate Body Report, was adopted by the DSB on 23 May 1997.

6. Canada - Certain Measures Concerning Periodicals, complaint by the United States. The panel established on 19 June 1996 found ... the measure applied by Canada to be in violation of GATT rules. Following an appeal by Canada, the Appellate Body upheld the panel's findings and conclusions on the applicability of GATT 1994 to Part V.1 of Canada's Excise Tax Act, but reversed the panel's finding that Part V.1 of the Act was inconsistent with the first sentence of Article III:2 of GATT 1994. The Appellate Body further concluded that Part V. 1 of the Excise Act was inconsistent with the second sentence of Article III:2 of GATT 1994. The Appellate Body also reversed the panel's conclusion that Canada's funded postal rate scheme was justified by Article III:8(b) of GATT 1994. The Appellate Body Report, together with the panel report as modified by the Appellate Body Report, was adopted by the DSB on 30 July 1997.

7. European Communities - Regime for the Importation, Sale and Distribution of Bananas, complaints by Ecuador, Guatemala, Honduras, Mexico, and the United States. The panel established on 8 May 1996 found that the EC's banana import regime and the licensing procedures for the importation of bananas in this regime are inconsistent with various provisions of the GATT, the Import Licensing Agreement and the GATS. Following an appeal from the EC, the Appellate Body upheld most of the panel's findings that the EC regime was inconsistent with the WTO rules. The Appellate Body Report, together with the panel report as modified by the Appellate Body Report, was adopted by the DSB on 25 September 1997. 
Negotiated settlements: An interesting feature of the WTO dispute settlement practice is that about one quarter of the disputes have not progressed to the adjudication phase, but were resolved by the parties themselves at the consultation stage. This outcome amply justifies the decision of the drafters that the interpolation of a negotiation mechanism along with [a] formal adjudication process would render the dispute settlement mechanism more effective. The instances of such negotiated settlements are listed below:

\begin{tabular}{|c|c|c|c|}
\hline & Complainant & Subject of complaint & Status \\
\hline 1. & Singapore & $\begin{array}{l}\text { Malaysia: Prohibition of imports of } \\
\text { polyethylene }\end{array}$ & Complaint withdrawn \\
\hline 2. & United States & $\begin{array}{l}\text { Korea: Measures concerning the shelf- } \\
\text { life of products }\end{array}$ & $\begin{array}{l}\text { Bilateral solution } \\
\text { notified }\end{array}$ \\
\hline 3. & Japan & $\begin{array}{l}\text { US: Imposition of import duties on auto- } \\
\text { mobiles from Japan }\end{array}$ & $\begin{array}{l}\text { Bilateral solution } \\
\text { notified }\end{array}$ \\
\hline 4. & Canada & EC: Trade description of scallops & Solution notified \\
\hline 5. & Canada & EC: Duties on imports of cereals & Appears settled \\
\hline 6. & Peru & EC: Trade description of scallops & Solution notified \\
\hline 7. & United States & EC: Duties on imports of grains & $\begin{array}{l}\text { Panel request with- } \\
\text { drawn }\end{array}$ \\
\hline 8. & Chile & EC: Trade description of scallops & Solution notified \\
\hline 9. & EC & $\begin{array}{l}\text { Japan: Measures affecting purchase of } \\
\text { telecom equipment }\end{array}$ & Appears settled \\
\hline 10. & India & Poland: Import regime for automobiles & $\begin{array}{l}\text { Bilateral solution } \\
\text { notified }\end{array}$ \\
\hline 11. & Canada & $\begin{array}{l}\text { Korea: Measures concerning bottled } \\
\text { water }\end{array}$ & $\begin{array}{l}\text { Bilateral solution } \\
\text { notified }\end{array}$ \\
\hline 12. & United States & $\begin{array}{l}\text { Japan: Measures concerning protection of } \\
\text { sound recordings }\end{array}$ & Bilateral solution \\
\hline 13. & India & $\begin{array}{l}\text { US: Measures affecting imports of } \\
\text { women's wool coats }\end{array}$ & Measures removed \\
\hline 14. & $\begin{array}{l}\text { Argentina, } \\
\text { Australia, } \\
\text { Canada, New } \\
\text { Zealand, Thai- } \\
\text { land, US }\end{array}$ & $\begin{array}{l}\text { Hungary: Export subsidies of agricultural } \\
\text { products }\end{array}$ & Solution notified \\
\hline
\end{tabular}




\begin{tabular}{|c|c|c|c|}
\hline & Complainant & Subject of complaint & Status \\
\hline 15. & United States & $\begin{array}{l}\text { Pakistan: Patent protection for pharma- } \\
\text { ceutical and agricultural chemical pro- } \\
\text { ducts }\end{array}$ & $\begin{array}{l}\text { Bilateral solution } \\
\text { notified }\end{array}$ \\
\hline 16. & United States & $\begin{array}{l}\text { Portugal: Patent protection under Indus- } \\
\text { trial Protection Act }\end{array}$ & $\begin{array}{l}\text { Bilateral solution } \\
\text { notified }\end{array}$ \\
\hline 17. & EC & $\begin{array}{l}\text { US: The Cuban Liberty and Democratic } \\
\text { Solidarity Act }\end{array}$ & $\begin{array}{l}\text { Panel suspended solu- } \\
\text { tion notified }\end{array}$ \\
\hline 18. & $\mathrm{EC}$ & $\begin{array}{l}\text { US: Tariff increases on products from } \\
\text { EC }\end{array}$ & Measures terminated \\
\hline 19. & US & $\begin{array}{l}\text { Turkey: Taxation of foreign film } \\
\text { revenues }\end{array}$ & $\begin{array}{l}\text { Bilateral solution } \\
\text { notified }\end{array}$ \\
\hline 20. & Mexico & $\begin{array}{l}\text { US: Anti-dumping investigations on fresh } \\
\text { and chilled tomatoes }\end{array}$ & Appears settled \\
\hline 21. & US & $\begin{array}{l}\text { Australia: Textile, clothing and footwear } \\
\text { import credit scheme }\end{array}$ & Appears settled \\
\hline 22. & EC & $\begin{array}{l}\text { Japan: Procurement of a navigational } \\
\text { satellite }\end{array}$ & $\begin{array}{l}\text { Bilateral solution } \\
\text { notified }\end{array}$ \\
\hline
\end{tabular}

Increased participation by developing countries: At much variance with the GATT practice, a new legal development in the WTO dispute settlement system is its frequent use by developing countries. As of August 1997, the developing countries have filed 31 cases and have been the subject of 37 complaints. Among the AALCC Member States, Japan, India, and Thailand have been the leading Complainants. The list of disputes wherein an AALCC Member State was involved whether as a complainant or as a subject of a Complaint is given below: ${ }^{92}$

\section{Participation of AALCC Member States in WTO Dispute Settlement Process}

\begin{tabular}{|l|l|l|}
\hline & Complainant & Subject of the complaint \\
\hline 1. & Singapore & $\begin{array}{l}\text { Malaysia: Prohibition of imports of polyethylene and } \\
\text { polypropylene }\end{array}$ \\
\hline 2. & United States & $\begin{array}{l}\text { Korea: Measures concerning the testing and inspection of } \\
\text { agricultural products }\end{array}$ \\
\hline
\end{tabular}

92 WTO Focus, August 1997. 


\begin{tabular}{|c|c|c|}
\hline & Complainant & Subject of the complaint \\
\hline 3. & United States & Korea: Measures concerning the shelf-life of products \\
\hline 4. & Japan & US: Imposition of import duties on automobiles from Japan \\
\hline 5. & EC & Japan: Taxes on alcoholic beverages \\
\hline 6. & Canada & Japan: Taxes on alcoholic beverages \\
\hline 7. & United States & Japan: Taxes on alcoholic beverages \\
\hline 8. & Thailand & EC: Import duties on rice \\
\hline 9. & India & Poland: Import regime for automobiles \\
\hline 10. & Canada & Korea: Measures concerning bottled water \\
\hline 11. & Philippines & Brazil: Measures affecting desiccated coconut \\
\hline 12. & United States & Japan: Measures concerning protection of sound recordings \\
\hline 13. & Hong Kong & $\begin{array}{l}\text { Turkey: Restrictions on imports of textiles and clothing } \\
\text { products }\end{array}$ \\
\hline 14. & Sri Lanka & $\begin{array}{l}\text { Brazil: Measures affecting desiccated coconut and coconut } \\
\text { milk powder }\end{array}$ \\
\hline 15. & India & $\begin{array}{l}\text { US: Measures affecting imports of women's and girls' wool } \\
\text { coats }\end{array}$ \\
\hline 16. & India & $\begin{array}{l}\text { US: Measures affecting imports of women's and girls' wool } \\
\text { coats }\end{array}$ \\
\hline 17. & India & $\begin{array}{l}\text { Turkey: Restrictions on imports of textiles and clothing } \\
\text { products }\end{array}$ \\
\hline 18. & Thailand and others & Hungary: Export subsidies of agricultural products \\
\hline 19. & United States & $\begin{array}{l}\text { Pakistan: Patent protection for pharmaceutical and agri- } \\
\text { cultural chemical products }\end{array}$ \\
\hline 20. & EC & $\begin{array}{l}\text { Korea: Laws, regulations and practices in the telecommuni- } \\
\text { cations sector }\end{array}$ \\
\hline 21. & United States & $\begin{array}{l}\text { Korea: Measures concerning inspection of agricultural } \\
\text { products }\end{array}$ \\
\hline 22. & $\mathrm{EC}$ & Japan: Measures concerning sound recordings \\
\hline 23. & United States & Turkey: Taxation of foreign film revenues \\
\hline 24. & United States & $\begin{array}{l}\text { Japan: Measures affecting consumer photographic film and } \\
\text { paper }\end{array}$ \\
\hline
\end{tabular}




\begin{tabular}{|c|c|c|}
\hline & Complainant & Subject of the complaint \\
\hline 25. & United States & Japan: Measures affecting distribution services \\
\hline 26. & Thailand & $\begin{array}{l}\text { Turkey: Restrictions on imports of textiles and clothing } \\
\text { products }\end{array}$ \\
\hline 27. & United States & $\begin{array}{l}\text { India: Patent protection for pharmaceutical and agricultural } \\
\text { chemical products }\end{array}$ \\
\hline 28. & Japan & Brazil: Certain automotive investment measures \\
\hline 29. & EC & $\begin{array}{l}\text { Indonesia: Certain measures affecting the automobile in- } \\
\text { dustry }\end{array}$ \\
\hline 30. & Japan & $\begin{array}{l}\text { Indonesia: Certain measures affecting the automobile indus- } \\
\text { try }\end{array}$ \\
\hline 31. & $\begin{array}{l}\text { Malaysia, Thailand, } \\
\text { India, Pakistan }\end{array}$ & $\begin{array}{l}\text { US: Import prohibition of certain shrimp and shrimp } \\
\text { products }\end{array}$ \\
\hline 32. & US & $\begin{array}{l}\text { Indonesia: Certain measures affecting the automobile } \\
\text { industry }\end{array}$ \\
\hline 33. & Philippines & $\begin{array}{l}\text { US: Import prohibition of certain shrimp and shrimp } \\
\text { products }\end{array}$ \\
\hline 34. & Japan & Indonesia: Certain automotive industry measures \\
\hline 35. & EC & Japan: Measures affecting imports of pork \\
\hline 36. & EC & Japan: Procurement of a navigational satellite \\
\hline 37. & US & Philippines: Measures affecting pork and poultry \\
\hline 38. & EC & Korea: Taxes on alcoholic beverages \\
\hline 39. & United States & Japan: Measures affecting agricultural products \\
\hline 40. & EC & $\begin{array}{l}\text { India: Patent protection for pharmaceutical and agricultural } \\
\text { chemical products }\end{array}$ \\
\hline 41. & United States & Korea: Taxes on alcoholic beverages \\
\hline 42. & Korea & $\begin{array}{l}\text { US: Imposition of anti-dumping duties on imports of colour } \\
\text { television receivers }\end{array}$ \\
\hline 43. & United States & $\begin{array}{l}\text { India: Quantitative restrictions on imports of agricultural, } \\
\text { textile and industrial products }\end{array}$ \\
\hline 44. & Australia & $\begin{array}{l}\text { India: Quantitative restrictions on imports of agricultural, } \\
\text { textile and industrial products }\end{array}$ \\
\hline
\end{tabular}




\begin{tabular}{|l|l|l|}
\hline & Complainant & Subject of the complaint \\
\hline 45. & Canada & $\begin{array}{l}\text { India: Quantitative restrictions on imports of agricultural, } \\
\text { textile and industrial products }\end{array}$ \\
\hline 46. & New Zealand & $\begin{array}{l}\text { India: Quantitative restrictions on imports of agricultural, } \\
\text { textile and industrial products }\end{array}$ \\
\hline 47. & Switzerland & $\begin{array}{l}\text { India: Quantitative restrictions on imports of agricultural, } \\
\text { textile and industrial products }\end{array}$ \\
\hline 48. & EC & $\begin{array}{l}\text { India: Quantitative restrictions on imports of agricultural, } \\
\text { textile and industrial products }\end{array}$ \\
\hline 49. & Japan & US: Measures affecting government procurement \\
\hline 50. & EC & $\begin{array}{l}\text { Korea: Definitive safeguard measure on imports of certain } \\
\text { dairy products }\end{array}$ \\
\hline 51. & Korea & $\begin{array}{l}\text { US: Anti-dumping duty on dynamic random access memory } \\
\text { semiconductors originating from Korea }\end{array}$ \\
\hline
\end{tabular}

\section{Secretariat Study: EXTRATERRITORIAL APPLICATION OF NATIONAL LEGISLATION: SANCTIONS IMPOSED AGAINST THIRD PARTIES} $\cdots$

The preliminary study prepared by the Secretariat [see 7 AsYIL 35 et seq.] and considered at the Thirty-sixth Session (Tehran, 1997) of the AALCC had pointed out that in the claims and counter-claims that had arisen with respect to the exercise of extraterritorial jurisdiction, the following principles have been invoked: (i) principles concerning jurisdiction; (ii) sovereignty, in particular economic sovereignty, and non-interference; (iii) genuine or substantial link between the State and the activity regulated; (iv) public policy and national interest; (v) lack of agreed prohibitions restricting [a State's] right to extend its jurisdiction; (vi) reciprocity or retaliation; and (vii) promotion of respect for law. Notwithstanding the national interests of the enacting State, grave concern was expressed on the promulgation and application of municipal legislation whose extraterritorial aspects affect the sovereignty of other States.

While a growing number of other States have applied their national laws and regulations on [an] extraterritorial basis, such fora as the General Assembly of the United Nations, the Group of 77, the Organization of Islamic Countries, the InterAmerican Juridical Committee and the European Economic Community have in various ways expressed concern about [the] promulgation and application of law and regulations whose extraterritorial effects affect the sovereignty of other States and the legitimate interests of entities and persons under their jurisdiction, as well as the freedom of trade and navigation. 
The study prepared by the Secretariat drew attention to the opinions of such august bodies as the Inter-American Juridical Committee, the Juridical Body of the Organization of American States ${ }^{93}$ and the International Chamber of Commerce ${ }^{94} 3$.

It [is] recalled in this regard that the AALCC study on the "Elements of Legal Instruments on Friendly and Good-Neighbourly Relations Between the States of Asia, Africa and the Pacific" had, inter alia, listed 34 norms and principles of international law, conducive to the promotion of friendly and good-neighbourly relations. The 34 principles enumerated, inter alia, included: (i) independence and State sovereignty; (ii) territorial integrity and [the] inviolability of frontiers; (iii) legal equality of States; (iv) non-intervention, overt or covert; (v) non-use of force; (vi) peaceful settlement of disputes; (vii) peaceful coexistence; and (viii) mutual cooperation. ${ }^{95}$

The study also pointed out that the use of unilateral action, particularly those with extraterritorial effects, can impede the efforts of developing countries in carrying out trade and macro-economic reforms aimed at sustained economic growth.

In the course of deliberations on this item at the Thirty-sixth Session [see 7 AsYIL pp.366-7] a view was expressed that sanctions could only be imposed by the Security Council after it had determined the existence of a threat to peace, a breach of [the] peace and act of aggression, and that unilateral sanctions were violative of the Vienna Declaration and Programme of Action of $1993^{96}$ which, inter alia, recognize the right to development. It was pointed out that unilateral sanctions were violative of the principle of non-intervention.

It was also stated that national laws having extraterritorial effect had no basis in international law and that such laws primarily aimed at individuals or legal persons were violative of the principle of non-intervention, political independence and territorial sovereignty enshrined in several treaties. Such acts, it was observed, were aimed at weaker developing countries.

Different views were expressed, such as: "extraterritorial application of national legislation would affect international trade" and "in a changing scenario of globalization of trade and privatization of economies, extraterritorial application of national laws would affect interdependence".

\footnotetext{
${ }^{93}$ For details see 35 International Legal Materials (1996) p.1322.

${ }^{94}$ DIETER LANGE AND GARY BORNE (eds.): The Extraterritorial Application of National Laws (ICC Publishing S.A.1987).

${ }^{95}$ AALCC Secretariat Study on "Elements of a Legal Instrument on Friendly and Good Neighbourly Relations between States of Asia, Africa and the Pacific". Reprinted in AALCC Combined Report of the Twenty Sixth to Thirtieth Sessions (New Delhi, 1992) p.192.

${ }^{96}$ The World Conference on Human Rights held in Vienna in 1993 had, inter alia, reaffirmed the right to development, as established in the Declaration on the Right to Development, as a universal and inalienable right and an integral part of fundamental human rights.
} 
Also, that the extraterritorial application of national legislation infringed the sovereign right of States, violated the principles of non-intervention, and affected the economic and political relations among States. Elaborating that sanctions would disturb the North-South relations, the Member States were called upon to voice their protest.

The United Nations General Assembly "Friendly Relations Declaration" was recalled and it was stated that although no State had the right to intervene directly or indirectly in the internal or external affairs of other States and every State had an inalienable right to choose its political, economic, social, and cultural systems without interference in any form by another State, large and powerful States were using it as a weapon. It was pointed out that a particular country had within a short span of four years imposed around sixty-four unilateral sanctions against thirty-five countries. In the present era, the notion of interdependency among States had become quite obvious and the principles of non-intervention and non-aggression, the two principles of the well-known five principles of peaceful coexistence, have become all the more obvious and were universally accepted by nations large or small, rich or poor. It was categorically stated that extraterritorial application of national laws had no basis whatsoever, legal, moral, or political. It blatantly violated the rules of international law and the rules of civilised law, and amounts to the infringement of [the] internal affairs of other countries.

It was observed that the Helms-Burton Act relating to trade with Cuba [and] the Kennedy-D'Amato Act relating to Libya, Iran, and Iraq were examples of extraterritorial application of national law in the form of sanctions against third parties. Even though superficially one might think that these national laws relate to actions by individuals, their object is the imposition of sanctions against States.

It may be recalled that while introducing the item at the Thirty-sixth Session (Tehran, 1997), the then Assistant Secretary-General had observed that although jurisdiction in matters of public law character is territorial in nature, some States are, however, known to give extraterritorial effect to their municipal legislation, which has resulted in conflict of jurisdictions and resentment on the part of other States. Civil Law countries exercise jurisdiction over their nationals for offenses committed even while they were abroad. Among the Common Law countries, [the] United Kingdom law allows such jurisdiction in select cases. The United States of America, however, exercises jurisdiction in a wide variety of cases. The National Association of Manufacturers has stated that "resort to unilateral sanctions may be justified in some cases; it may be rationalized in many more. But it can rarely, if ever, be explained."

The United States of America has armed itself with a plethora of laws which have hitherto allowed the Administration to extend its jurisdiction and impose uni- 
lateral sanctions against more than 70 States. ${ }^{97}$ According to [a] report of the Latin American Economic System (SELA), which groups 28 Latin American and Caribbean States, 76 States put up with or are seriously threatened by one or more trade sanctions. Unilateral trade sanctions severely threaten or punish 68 per cent of the world population. The President's Export Council report on sanctions listed 73 States that, as of January 1997, had been subjected to some form of unilateral sanctions.

A report commissioned and published by the United States National Association of Manufacturers (NAM) had, in March 1997, revealed that "from 1993 through 1996, 61 US laws and executive actions were enacted authorizing unilateral sanctions for foreign policy purposes. Thirty-five countries were specifically targeted". 98 The report had concluded that all economic sanctions "should be multilateral except in the most unusual and extreme circumstances".

Senator Jesse Helms, one of the promoters of the Helms-Burton Act, has, however, questioned the validity of the report of the National Association of Manufacturers. ${ }^{99}$ According to ... [Helms], "between 1993 and 1996, the Congress passed and the President signed a grand total of five new sanctions laws: the Nuclear Proliferation Prevention Act, 1994; the Cuban Liberty and Democratic Solidarity Act of 1996; the Antiterrorism and Effective Death Penalty Act of 1996; the Iran Libya Sanctions Act, 1996; and the Free Burma Act, 1996." He goes on to emphasize that during "the same period, the President imposed just four new sanctions: declaring Sudan a terrorist state; banning imports of munitions and ammunition from China; tightening travel-related restrictions, cash remittance levels, and the sending of gift parcels to Cuba (restrictions that have since been lifted); and imposing a ban on new contractual agreements or investments in Iran". ${ }^{100}$ On the other hand, the former Secretary of State, Henry A. Kissinger, has observed that "these congressionally mandated sanctions are threatening to place American policy into a straitjacket".

\footnotetext{
${ }^{97}$ The targeted States include Afghanistan, Algeria, Angola, Armenia, Azerbaijan, Bahrain, Bangladesh, Belarus, Belize, Burma [sic], Burundi, Cambodia, Canada, China, Colombia, Costa Rica, Cuba, Djibouti, Egypt, Gambia, Georgia, Guatemala, Haiti, Honduras, Islamic Republic of Iran, Iraq, Italy, Japan, Jordan, Kazakhstan, Kuwait, Kyrgyzstan, Laos, Lebanon, Liberia, Libya, Maldives, Mauritania, Mexico, Moldova, Morocco, Nigeria, North Korea, Oman, Pakistan, Panama, Paraguay, Qatar, Romania, Russia, Rwanda, Saudi Arabia, Somalia, Sri Lanka, Sudan, Syria, Taiwan, Tajikistan, Tanzania, Thailand, Turkmenistan, Uganda, Ukraine, United Arab Emirates, Uzbekistan, Vanuatu, Venezuela, Vietnam, Yemen, Federal Republic of Yugoslavia, and Zaire. In addition to these States unilateral sanctions have also been targeted at other newly independent States of the erstwhile Soviet Russia [sic] and India. in addition to these States, Indonesia and Malaysia are considered to be among the possible targets.

${ }^{98}$ See A Catalog of New US Unilateral Economic Sanctions for Foreign Policy Purposes 1993-96 (with Analysis and Recommendations), March 1997. The Catalog was prepared under the direction of PROFESSOR BARRY CARTER of Georgetown University Law School. The analysis and recommendations were prepared by Marino Marcich of the NAM Trade and Technology Policy Department. For the text of the Catalog visit http://www.usaengage.org/studies/nam.html.

${ }^{99}$ The list of administrative actions taken by individual government agencies was compiled by the Georgetown University Law Center.

${ }^{100}$ SENATOR JeSSE HELMS: "What Sanctions Epidemic?: U.S. Business Curious Crusade", Foreign Affairs, January-February 1999.
} 


\section{Reasons for the Imposition of Unilateral Sanctions}

It may be stated that the reasons for the imposition of unilateral sanctions have ranged from boycott activity ${ }^{101}$ to the issue of [workers'] rights, ${ }^{102}$ and have hitherto included such other issues as communism, ${ }^{103}$ transition to democracy, ${ }^{104}$ environmental activity, expropriation, ${ }^{105}$ harbouring war criminals, human rights, ${ }^{106}$ market reform, military aggression, narcotics activity, political stability, [and the] proliferation of weapons of mass destruction and terrorism. ${ }^{107}$ The Federal legislation invoked to impose unilateral sanctions and/or impose secondary boycott have included the Andean Trade Preference Act; the Antiterrorism and Effective Death Penalty Act, 1996 (Antiterrorism, 1996); the Arms Export Control Act (AECA); the Atomic Energy Act; the Cuban Democracy Act, 1992; the Cuban Liberty and Democratic Solidarity Act, 1996 (Helms-Burton or LIBERTAD Act); the Department of Commerce, Justice and State, the Judiciary, and Related Agencies Appropriations Act, 1990 (Commerce Appropriations, 1990); the Department of Defense Appropriations Act, 1987 (Defense Appropriations, 1987); the Export Administration Act; the Export-Import Bank Act ("Ex-Im"); the Fisherman's Protective Act, 1967; the Foreign Assistance Act (FAA); [the] Foreign Relations Act; the Foreign Relations Authorization Act; the Foreign Operations, Export, Financing and Related Programs Appropriation Act, 1995; the General System of Preferences Renewal Act (GSP); the High Seas Drift Net Fisheries Enforcement Act (Drift Net Act); the Internal Emergency Economic Powers Act (IEEPA); the Internal Revenue Code; the Internal Security and Development Cooperation Act, 1985 (ISDCA); the International Financial Institutions Act; the Iran-Iraq Non-Proliferation Act, 1992; the Iran and Libya Sanctions Act, 1996; the Iraq Sanctions Act, 1990; the Marine Mammal Protection Act, 1972 (Marine Act); the Narcotics Control Trade Act; ${ }^{108}$ the National Defense Authorization Act, 1996 (Defense Authorization Act, 1996); the Nuclear Non-Proliferation Act, 1994 (NNPA); the Omnibus Appropriation Act, 1997 (1997 Omnibus); the Spills of War Act; the Trade Act, 1974 (Trade Act); [the] Trading with the Enemy Act (TWEA).

\footnotetext{
${ }^{101}$ See the Foreign Relations Act 1994.

${ }^{102}$ See the Andean Trade Preference Act.

${ }^{103}$ Aimed at Cuba and North Korea. See the Cuba Regulation and the North Korea Regulations.

${ }^{104}$ See the Cuban Democracy Act 1992.

${ }^{105}$ The Helms-Burton Act 1996.

${ }^{106}$ During 1993-96, human rights and democratization were the most frequently cited objectives [of] foreign policy and thirteen countries were specifically targeted, with 22 measures adopted.

107 The Iran-Libya Sanctions Act 1996. The former Representative TOBY ROTH criticized the IranLibya Sanctions Act as "good politics ... but bad law". Its only effect, he said, "so far had been to unify the European Union, all 15 members, against the US policy toward Iran and Libya".

${ }^{108}$ The uncertified drug producing/transit countries are Afghanistan, Burma (sic), Colombia, Iran, Nigeria and Syria.
} 


\section{Executive Orders/Presidential Determinations}

During 1997-8 there have been four instances of unilateral imposition of sanctions by Executive Orders and Presidential Determinations. These include Executive Order 13047 of 21 May 1997 invoking a prohibition on new investment in Burma (Myanmar); Executive Order 13067 of 3 November 1997, imposing a comprehensive trade embargo on Sudan; Presidential Determination No. 98-22 of 13 May 1997 prohibiting the sale of specific goods and technology, and United States Bank loans to the Government of India; terminating sales of defence articles and design and construction equipment and services, and shutting down the Export-Import Bank (Ex-Im), Overseas Private Investment Corporation (OPIC) and TDA; and Presidential Determination No. 98-XX of 30 May 1998, prohibiting the sale of specific goods and technology and United States Bank loans to the Government of Pakistan, terminating sales of defence articles and design and construction equipment and services, and shutting down Ex-Im, OPIC and TDA.

\section{State and Local Sanctions Acts}

In addition to the Federal legislation, State and Local Governments have been increasingly inclined over the last year and a half to impose sanctions against foreign countries in response to human rights practices. Some twelve US States, Countries and cities have sought to establish their own measure against other Countries and have imposed restrictions against States ranging from Myanmar to Switzerland. Thus, following the imposition of United States investments sanctions on Myanmar in May $1997^{109}$ a dozen or so local governments restricted the granting of public contracts to companies that do business with Myanmar. These include the Commonwealth of Massachusetts, the cities of San Francisco and Oakland, California, and several other Governments that have enacted "selective purchasing ordinances" against domestic and foreign companies that do business with Myanmar. Some States have been contemplating similar procurement restrictions against companies that deal with Indonesia.

The "Massachusetts Burma Law" of $1996^{110}$ was characterized by the United States District Court of the State of Massachusetts as infringing "on the Federal

\footnotetext{
${ }^{109}$ See Executive Order 13047 of 20 May 1997. In imposing the investment ban the President is said to have exercised authority given by an amendment to the fiscal year 1997 Foreign Operations Appropriation Act.

${ }^{110}$ See Massachusetts Act of 25 June 1996. The State of Massachusetts admitted before the District Court of Appeal that the Statute "was enacted solely to sanction Myanmar for human rights violations and to change Myanmar's domestic policy".
} 
Government's power to regulate foreign affairs". In reaching its conclusion the Court had, inter alia, relied on an amicus curiae brief filed by the European Union. ${ }^{111}$

In its amicus curiae brief the European Union had called to the Court's attention the following points: (i) the Massachusetts Burma Law interferes with the normal conduct of EU-US relations; (ii) the Massachusetts Burma Law has created a significant issue in EU-US relations including raising questions about the ability of the United States to honour international commitments it has entered into in the framework of the World Trade Organization (WTO); and (iii) failure to invalidate the Massachusetts Burma Law risks a proliferation of similar non-federal sanctions laws, aggravating these effects. As regards the first point it was stated that the Massachusetts Burma Law "constitutes a direct interference with the ability of the EU to cooperate and carry out foreign trade with the United States ... The Massachusetts Burma Law is thus aimed at influencing the foreign policy choices of the Union and its Member States, and at sanctioning the activities of EU companies which are not only taking place in a third Country but which are also lawful under EU and Member States' laws".

As to the impugned Massachusetts Burma Law having created an issue of serious concern in EU-US relations, the amicus curiae brief stated that the "Massachusetts Burma Law charts a very different course. It is a secondary boycott: an extraterritorial economic sanction that is targeted not at the regime, but at nationals of third countries that may do business with Burma".

Finally, the European Union expressed its concern that the failure to enjoin the Massachusetts Burma Law will lead to the proliferation of US State and Local sanctions laws, and stated that at least six US municipalities had enacted measures purporting to regulate business activities in Nigeria, Tibet, and Cuba, and eighteen States and Local Governments had considered or "were considering similar measures restricting business ties to Switzerland, Egypt, Saudi Arabia, Pakistan, Turkey, Iran, North Korea, Iraq, Morocco, Laos, Vietnam Indonesia or China”. It emphasized that "the United States and the European Union had expended considerable effort in seeking to resolve their differences over US extraterritorial economic sanctions" and that "this effort has not yielded progress on the issue of extraterritorial sanctions" imposed by State and Local Governments, a shortcoming that is of considerable concern to the US [sic; EU?]. It went on to recall that in recognition of this danger of proliferation of sanctions measures, the EU-US agreed at the EU-US Summit on 18 May 1998 on a set of principles covering the future use of sanctions in the context of the Transatlantic Partnership on Political Cooperation. This included agreeing that the EU and the US "will not seek or propose, and will resist, the passage of new economic sanctions legislation based on foreign policy grounds which is designed to make economic operators of the other behave in a manner similar to that required

${ }^{111}$ See the judgment of the Court of 4 November 1998 in National Foreign Trade Council vs. Charles D. Baker, in his official capacity as Secretary of Administration and Finance of the Commonwealth of Massachusetts and Philmore Anderson III in his official capacity as a State Purchasing Agent for the Commonwealth of Massachusetts. 
of its own economic operators and that such sanctions will be targeted directly and specifically against those responsible for the problem. ${ }^{112}$

The validity of punitive measures against Myanmar adopted by State and Municipal Governments and ordinance in the United States have been analysed under various provisions of the United States Constitution and it has been said that such local measures are constitutionally infirm. ${ }^{113}$ It has been pointed out in this regard that "Article VI of the Constitution provides that the laws and treaties of the United States are 'the Supreme Law of the Land' and prevail over, or pre-empt, State and Local enactments. Thus any local law that purports to regulate or govern a matter explicitly covered by federal legislation is pre-empted, even if it is an area otherwise amenable to state regulation". 114

\section{The Banana War}

The United States had last year accused the European Union of not complying with a ruling of the World Trade Organization (WTO) calling upon it to change its banana import regime, which had been ruled illegal because it favoured the produce of African, Caribbean and Pacific States (hereinafter called the ACP States), and had discriminated against imports of fruit marketed mainly by United States companies in Latin America. The European Union on its part believes that it has rectified the situation by making changes to its regime with effect from 1 January 1999, but the amendments are seen as being derisory by the United States, which has argued that it is within its rights to retaliate.

In October 1998 the United States Administration announced a series of steps that would lead to the imposition of trade sanctions under Section 301 of the Trade Act of 1974 against the European Communities by March 1999 in retaliation for what the US claims to be an incorrect implementation of the $\mathrm{DSB}^{115}$ recommendations in the banana dispute. The United States of America had announced retaliatory 100 per cent tariffs on 520 million dollars worth of imports of EC products should it find that the EC had failed to implement the DSB recommendations. A unilateral determination by the US Administration would violate the fundamental obligations of the WTO's Dispute Settlement Understanding. A unilateral decision to restrict imports from the EC would also violate substantive obligations such as those incorpor-

\footnotetext{
${ }^{112}$ See the Amicus Curiae Brief of 13 August 1998 filed by the European Union in support of the Plaintiff, [the] National Foreign Trade Council, in National Foreign Trade Council vs. Charles D. Baker and Philmore Anderson III. Emphasis added.

${ }^{113}$ DAVID SCHMAHMANN AND JAMES FINCH: "The Unconstitutionality of State and Local Enactments in the United States Restricting Trade Ties with Burma", Vanderbilt Journal of International Law Vol.30 (1997).

${ }^{114}$ Ibid.

115 The Complainants in the dispute before the Dispute Settlement Body of the WTO had included Ecuador, Guatemala, Honduras, Mexico, and the United States of America.
} 
ated in Articles I, II, and XI of GATT 1994. An overwhelming majority of the WTO members ${ }^{116}$ are opposed to US embarking on unilateral action on this issue.

The threat to retaliate against the EU results from a unilateral judgment that the EU has not complied with a WTO ruling "condemning" [the] EU banana import regime, and the conflict has raised serious issues of interpretation of WTO laws and brought to light ambiguities in the WTO rule book.

\section{Fifty-third Session of the General Assembly}

The General Assembly at its recently concluded Fifty-third Session had expressed its concern at the continued promulgation and application of laws and regulations the extraterritorial effects of which affect the sovereignty of other States, the legitimate interests of entities or persons under their jurisdiction, and the freedom of trade and navigation. It took note of the declarations and resolutions of different intergovernmental forums, bodies and Governments that expressed the rejection by the international community and by public opinion of the promulgation and application of such regulations, and [...] reiterated its call to all States to refrain from promulgating and applying laws and measures the extraterritorial effects of which affect the sovereignty of other States [and] the legitimate interests of entities or persons, "in conformity with their obligations under the Charter of the United Nations and international law which, inter alia, reaffirmed the freedom of trade and navigation". 117

\section{Comments and observations}

As the Catalog of New US Unilateral Economic Sanctions for Foreign Policy Purposes 1993-6 revealed, the United States is resorting increasingly to unilateral economic sanctions against a broad range of countries for a wide variety of reasons. Apart from the increase in the instances of unilateral imposition of sanctions has been [sic] the additional development of "secondary boycott measures, which extended the reach of the United States law to overseas companies doing business in the targeted countries". The unilateral imposition of sanctions is at the core of the problem of extraterritorial application of national legislation.

Owing to its extraterritorial reach the imposition of unilateral sanctions for foreign policy purposes has often caused a new set of commercial problems with allies, as it did in the instances of both the Helms-Burton Act and the D'Amato-Kenenedy Act. The abrogation, annulment, or revocation of extraterritorial provisions and Acts would require a new Act.

Just as the validity or constitutionality of municipal, local and state laws must be tested with[in] the framework and parameters of the Constitution of that State,

\footnotetext{
${ }^{116}$ At present 133 States are Members of the World Trade Organization.

${ }^{117}$ See General Assembly Resolution 53/4 of 22 October 1998 on the "Necessity of ending the economic, commercial and financial embargo imposed by the United States of America against Cuba".
} 
the vires of the national legislation which imposes unilateral sanctions and has extraterritorial reach must be examined in the context of the provisions of the Charter of the United Nations and other international instruments which that State has negotiated and ratified. The preliminary study prepared by the Secretariat had emphasized this point and had sought to demonstrate that national legislation with extraterritorial reach contravenes not one or two, but several norms and principles of contemporary international law.

Many of these international instruments had been negotiated, concluded, and brought into force to establish a rule-based system and to promote the rule of law in international relations. This is particularly true to [sic] international economic and trade relations where such legislation poses a challenge to the avowed objective of the international community to establish a rule-based system to ensure stability and predictability in international trade relations. National legislation with extraterritorial reach, explicit implicit [sic], undermines the further redevelopment and growth of the rule-based system that the members of the international community are endeavouring to evolve. Such legislation, apart from sapping the principle of rule of law in inter-state relations, poses a challenge nay [sic] a threat, to the avowed objective of the international community to make international law the language of international relations in the next millennia.

\section{E. REPORT OF THE RAPPORTEUR OF THE SPECIAL MEETING ON THE RESERVATION TO TREATIES held on 14 April 1998}

The view was expressed that while the Vienna regime of reservations to treaties was based on the assumption that a multilateral treaty is in effect a combination of several bilateral treaty relationships, there were a certain category of treaties which, by the very nature of the subject matter addressed by them, did not admit of any reservations. Treaties relating to the protection and preservation of the environment [treaties], disarmament treaties, and human rights treaties were identified as the category of treaties which are applicable and binding upon not only the States Parties, but on all members of the international society. The United Nations Convention on the Law of the Sea 1982 was yet another example of a treaty which by the nature of being a "package deal" did not admit of reservations.

The Special Meeting considered the functions and role as well as the competence of the monitoring bodies to appreciate or determine the admissibility of a reservation. The view of the Commission that the legal force of the findings made by such bodies in the exercise of their functions could not exceed those resulting from the powers given to them, met with approval. However, the suggestion of providing specific clauses in normative multilateral treaties or elaborating protocols to confer competence on the monitoring body to appreciate or determine the admissibility of a reservation met with resistance.

Many of the participants addressed themselves to the provisions of the international instruments on human rights. The right to religion, the right to work, [the] 
right to health, and the right to compulsory education were among those that were cited and debated. Several views were expressed on the specific provisions of human rights treaties and the reservations thereto. While some identified the lack of resources, unrealistically high international human rights standards, among others, some participants listed the different socio-economic, cultural, and political backgrounds of the people and States as the reasons for the formulation of reservations to human rights treaties. It was pointed out that the provisions of some of the human rights treaties could be sub-classified as those (i) requiring intervention of States and (ii) those not requiring any action or intervention by States Parties.

\section{Points of convergence}

The deliberations in the Seminar revealed a convergence of views on a wide range of issues. These included:

(i) The law of reservation ushered in by the Vienna Convention has, by and large, served well the needs of the international community of States. It may be unwise to derail the Vienna regime on reservations. The provisions of the Vienna Convention on Treaties had been [sic] and continue to enjoy wider acceptance. Inasmuch as these provisions had stood the test of time they should not be tampered with. There was no need to amend or alter them. The majority of participants were of the view that the right to formulate and express reservations to one or more provisions of a convention is an attribute of State sovereignty, and power to make or express reservations can only be restricted by a treaty.

(ii) The existing regime of reservations as incorporated in Articles 19 to 23 of the Vienna Convention on [the] Law of Treaties, 1969, were sufficiently flexible and, whilst recognizing the inherent right of a State to make a reservation, merely restricted that right by stipulating that the reservation or declaration made by a State be "compatible with the object and purpose of the treaty concerned". In this regard it was pointed out that the Commission itself had, in paragraph 1 of the Preliminary Conclusions on Reservations to Normative Multilateral Treaties Including Human Rights Treaties, [...] recognized that "Articles 19 to 23 of the Vienna Conventions on the Law of Treaties of 1969 and 1986 govern the regime of reservations to treaties and that, in particular, the object and purpose of the treaty is the most important of the criteria for determining the admissibility of reservations". It (the Commission) "considers that, because of its flexibility, this regime is suited to the requirements of all treaties, of whatever object or nature, and achieves a satisfactory balance between the objectives of preservation of the integrity of the text of the treaty and universality of participation in the treaty".

The view was expressed that a monitoring body lacked the competence to adjudge the admissibility or legality of a reservation unless it had been expressed that a strict regime of reservations with a monitoring body at its apex would impair the objective of universality of participation in the treaty. The treaty regime including the regime 
of reservations should aim at promoting the objective of universality of participation rather than hinder the process of ratification.

(iii) Although one expert had categorized treaties as (a) treaties valid erga omnes; (b) constitutive treaties; (c) humanitarian conventions/treaties, and (d) codification treaties, the majority view was that, while such a classification was useful, no distinction needed to be drawn between human rights treaties and other treaties with respect to the regime of reservations. One expert raised the question whether reservations to human rights treaties were any different from reservations to other normative treaties. Almost all treaties stipulate normative and contractual obligations. The question was also posed whether human rights treaties deserve to be classified in the category of treaties which admit of no reservations. It was pointed out in this regard that the Human Rights Covenants had been adopted a good [sic] two years before the Conference on the Law of Treaties was convened in 1968 and that the Vienna Conference on the Law of Treaties had not deemed it necessary to differentiate human rights treaties from any other set of normative treaties. It was stated in this regard that what the conference of plenipotentiaries had not done the International Law Commission could not do because what cannot be done directly can not be done indirectly.

(iv) Insofar as paragraph 3 of the Preliminary Conclusions adopted by the Commission sought to differentiate between normative treaties and treaties in the field of human rights, the participants in the Special Meeting could not agree with the formulation or text of paragraph 3 .

(v) Most participants could not accept paragraph 5 of the Preliminary Conclusions adopted by the International Law Commission relating to the role of the monitoring bodies of human rights treaties. One expert took exception to the use of the term "monitoring body" since the term "monitor" implied an element of surveillance. He therefore proposed the use of the term "supervisory body" in lieu of the present term "monitoring body" employed by the Commission. Yet another expert was of the view that the proposed role of the monitoring bodies was a dangerous proposition. It was stated in this regard that the passing of value judgments on the admissibility of reservations and the practice of States by a monitoring body would be unacceptable to States. A third expert characterized the proposed role and function of monitoring bodies, as regards the admissibility of reservations to human rights treaties, as the opening of Pandora's box. A participant from one member state expressed the view that formulation of a reservation constitutes [the] sovereign right of States and [that] the provision embodied in paragraph 5 of the Preliminary Conclusions is in contradiction with this cardinal principle of the Law of Treaties.

(vi) The view was also expressed that, while the monitoring bodies ought [sic; ought not?] to make value judgments on the validity or otherwise of a reservation to a treaty, they could, however, make recommendations as to the effect of a reservation. 
(vii) Paragraph 10 of the Preliminary Conclusions was considered by some to be a "creeping" clause and one that may be amenable to misuse. It was stated in this regard that the Commission should avoid handing out political handles (sic) that could result in the defeat of the very object of universality of participation in a treaty.

\section{Recommendations}

A number of recommendations was made in the course of the Special Meeting. The proposals advanced included:

(i) One view suggested that the International Law Commission undertake an empirical study of state behaviour and study the reservations to treaties and, if feasible, the motives thereof. It could thereafter seek to develop the reservation regime by way of "interpretative codification".

(ii) Another view emphasized the universal acceptability of the existing reservation regime and proposed that the gaps and lacunae could be filled by commentaries on the existing provisions of the Vienna Convention. He favoured the preparation of a guide to state practice rather than the formulation of model clauses or a protocol.

(iii) It was recommended that the ILC consider concluding its work on this topic not on the basis of "intuitive feeling" but on the basis of an empirical study of the behaviour of States.

(iv) The Commission should approach its future work on the subject with due caution and [should] not be guided by the European precedents, which may not always be relevant or appropriate to the universal context. One view was that a realistic stance would require taking note of the different political, social, economic, and cultural milieux of the States and accepting some reservations to treaties as the price to be paid for the promotion and achievement of universality.

(v) The Secretariat should report the debate of the Special Meeting to the International Law Commission. It also requested the Representative of the International Law Commission to report his findings to the Commission at its forthcoming 50th Session.

F. Secretariat Study: SPECIAL MEETING ON EFFECTIVE MEANS OF IMPLEMENTATION, ENFORCEMENT AND DISPUTE SETTLEMENT IN INTERNATIONAL ENVIRONMENTAL LAW

\section{Conclusions}

The existing normative framework of international environmental law is presently characterized by an abundance of multilateral conventions and other international 
instruments. As rightly articulated by Ambassador Chusei Yamada, Member of the ILC, "the sector by sector approach which has been adopted so far in the conclusion of various multilateral conventions, often dictated by the need to respond to urgent and specific requirements, runs the risk of not addressing the need for an integrated approach to the prevention of pollution and continuing deterioration of the global environment". ${ }^{118}$ The uncertainty over the normative framework is equally relevant in the study of effective means of implementation, enforcement, and dispute settlement in international environmental law. Certain aspects of this incongruity between the traditional approaches premised on sovereign equality of territorial States and the broader concern to preserve the global environment, in the sphere of implementation and enforcement has been briefly outlined in this background note. Besides such conceptual difficulty in issues concerning implementation in developing Countries is the lack of resources and technology, and the absence of trained personnel.

While the task of evolving fair and workable legal principles towards conserving the global environment is equally important, yet if the existing patch-work of environmental regimes are to be consolidated, the AALCC needs to consider the specific infrastructural and legal impediments facing implementation and enforcement in the Afro-Asian region. It is hoped that this Background Note would provide the backdrop for the AALCC Member States to deliberate on country-specific issues encountered in the process of implementation, enforcement and dispute settlement.

${ }^{118}$ See ILC document ILC (L) INFORMAL/22 entitled “Long-term Programme of Work: Feasibility study of the law of environment". 